\title{
La gruta de Cacahuamilpa: un siglo de historia (1835-1936)
}

\section{The Cacahuamilpa Grotto: a Century of History (1835-1936)}

\author{
Guadalupe C. Gómez-Aguado de Alba \\ Centro de Enseñanza para Extranjeros-UnAM \\ gucega@hotmail.com
}

José Luis Palacio Prieto

Instituto de Geografía-UNAM

palacio@unam.mx

\begin{abstract}
Resumen
A partir de su descubrimiento, la gruta de Cacahuamilpa ha sido un destino común para mexicanos y extranjeros durante casi dos siglos. Sin embargo, los estudios formales sobre ese monumento natural son escasos y en ellos abundan las inexactitudes. A partir de fuentes primarias, artículos periodísticos y libros referidos a la caverna, este trabajo hace un recuento de su historia y ofrece una imagen del México decimonónico y los albores del siglo xx. Las impresiones de los primeros viajeros que recorrieron la caverna, el estado de los caminos; los cambios políticos; la inquietud de formar asociaciones científicas y literarias; la preocupación por la conservación del medioambiente; el desarrollo de las inversiones en infraestructura; las primeras instalaciones de luz eléctrica y, finalmente, la trasformación de Cacahuamilpa en Parque Nacional en 1936, son algunos de los temas abordados en este trabajo. La historia de un célebre monumento natural nos servirá para hacer un recorrido por un siglo de la historia de México.
\end{abstract}

Palabras clave: gruta; Cacahuamilpa; viajeros; inversiones; caminos.

\section{Abstract}

Since its discovery, the Cacahuamilpa Grotto has attracted Mexicans and foreign travelers for almost two centuries. However, formal studies of this natural monument are scarce and full of inaccuracies. This paper uses primary sources, newspaper articles and books on the cavern to trace its history, and offer an image of Mexico in the 19th and early zoth centuries. The topics discussed include the impressions of the first travelers to visit the cavern; the state of the roads; political changes; the interest in creating scientific and literary associations; the concern with environmental conservation; the development of infrastructure investment; the first electrical installations; and lastly, Cacahuamilpa's transformation into a National Park in 1936. The experiences of a famous natural monument provide an opportunity to revisit a century of Mexican history.

Key words: Grotto; Cacahuamilpa; travelers; investment; paths.

Fecha de recepción: 26 de agosto de 2014 Fecha de aceptación: 13 de octubre de 2014 


\section{La gruta de Cacahuamilpa: un siglo de historia $(1835-1936)^{*}$}

\section{Guadalupe C. Gómez-Aguado de Alba José Luis Palacio Prieto}

I a gruta de Cacahuamilpa es la caverna más conocida, estudiada y via 150 kilómetros al sur de la ciudad de México, en el estado de Guerrero, próxima al límite con los actuales estados de Morelos y México, ha sido recorrida por mexicanos y extranjeros desde su descubrimiento en la tercera década del siglo xix. Sin embargo, los estudios formales sobre ese monumento natural son escasos y en ellos abundan las leyendas e inexactitudes. De ahí que este trabajo aborde la historia de la caverna a lo largo de un siglo con la intención de acercarse al México decimonónico y al de los albores del siglo xx desde el punto de vista de la imagen de Cacahuamilpa en las publicaciones de la época, así como desde la forma en que la caverna fue vista como un medio de promover la riqueza natural de México, así como de fomentar las inversiones. De ese modo, mediante el análisis de fuentes primarias, artículos periodísticos y referencias bibliográficas, podremos adentrarnos en la historia mexicana desde un enfoque cultural, es decir, a partir de la construcción de la realidad por medio de las representaciones, en este caso, de la gruta de Cacahuamilpa. Si a decir de Peter Burke (2012, pp. 97-103), el discurso "construye" el objeto del que se habla y toda la historia es historia cultural, las imágenes y los textos que nos han servido como fuentes primarias para elaborar este trabajo no se limitan a reflejar o imitar la realidad, sino que la reinterpretan y le dan un sentido y una orientación definidos según los intereses de sus autores y el público a quien iban dirigidos.

El artículo está dividido en cuatro grandes apartados, cada uno relativo a un periodo cronológico y con un sentido específico, si bien el tema

* Este trabajo contó con el apoyo de la Dirección General de Apoyo al Personal Académico (DGAPA-UNAM), proyecto IN100714. 
de estudio es la gruta de Cacahuamilpa. El primero se dedica a analizar los escritos pioneros sobre la caverna, de carácter descriptivo, llenos de narraciones fantásticas y en los que la intención de sus autores era dar una visión lo más colorida posible de un fenómeno natural extraordinario. Dirigidos a un público lector sin formación científica, extraídos de la prensa periódica o de diarios de viaje, estos buscaban entretener más que informar. En el segundo apartado se estudian los primeros artículos científicos que se publicaron sobre Cacahuamilpa, así como las noticias aparecidas en la prensa de la época sobre las visitas con fines de exploración o de entretenimiento de personajes ilustres a la cada vez más famosa caverna, según lo que narran las crónicas. La intención de sus autores en la mayoría de las veces fue promover las excursiones al sitio como una manera de dar a conocer a México en el mundo. En la tercera parte se estudian principalmente artículos periodísticos que buscaban fomentar las inversiones en redes ferroviarias y caminos, así como convertir a Cacahuamilpa en un destino turístico que redituara beneficios a sus promotores. Al igual que en los casos antes mencionados, los autores de las notas de prensa tenían intereses muy claros. Finalmente, la última parte del trabajo hace un breve recuento de las menciones sobre la gruta en los albores del siglo $\mathrm{xx}$, cuando ya era un destino turístico ineludible para excursionistas nacionales y extranjeros que visitaban la ciudad de México y sus alrededores; en ese sentido, las fuentes bibliográficas utilizadas fueron básicamente una descripción del camino y de la caverna desde el punto de vista geológico, así como una crónica literaria, es decir, la caverna era objeto, también en el siglo $\mathrm{xx}$, de atención científica y artística. Al mismo tiempo, como parte de los cuatro apartados mencionados, la interpretación de las fuentes permitirá al lector conocer el desarrollo de los medios de transporte y de los caminos en México a lo largo de una centuria, y algunos mitos y leyendas que se han tejido en torno a sus visitantes ilustres y sobre los hallazgos encontrados en el interior de la gruta.

De esa manera, al saber la forma en que ese monumento natural fue visto e interpretado a partir de los particulares intereses que los excursionistas, promotores, científicos e inversionistas quisieron plasmar en las fuentes escritas sobre la célebre caverna, se podrá conocer un siglo de historia de México desde el punto de vista del imaginario construido en torno a Cacahuamilpa.

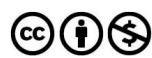




\section{LAS PRIMERAS EXPEDICIONES (1834-1850)}

Se cree que la gruta de Cacahuamilpa fue conocida por los habitantes originarios de la región en que se ubica. En el primer artículo publicado sobre la caverna, se afirmaba que esta pudo servir "al culto de los antiguos mexicanos; y las ruinas de un edificio a manera de altar que se conservan en la cima de una montaña al frente de su entrada favorecen esta opinión" (Anónimo, 1838, pp. 159-183). En el último cuarto del siglo xIX, el geólogo Mariano Bárcena (1895, p. 75) reportó la existencia de utensilios de origen prehispánico hallados en excavaciones realizadas en el interior de la cueva. En 1971 se llevaron a cabo estudios sobre algunos enterramientos en los alrededores del sitio, en donde encontraron restos humanos correspondientes al periodo Preclásico, es decir, con una antigüedad de unos 3000 años. Los enterramientos fueron encontrados "a la altura del estacionamiento de la carretera que permite el acceso al río Chontalcoatlán” (Lagunas, 1976, pp. 41-46).

No obstante, las primeras menciones sobre la existencia de la gruta aparecen hasta la tercera década del siglo XIX. Ni siquiera el naturalista Alexander von Humboldt, quien visitó la cercana ciudad de Taxco a principios de esa centuria, habló de la caverna; de haberse conocido públicamente, sin duda el alemán no hubiera dejado de visitarla y de describirla en los detallados estudios que llevó a cabo sobre diversos aspectos del territorio mexicano. Por lo demás, las dificultades para llegar hasta allí por lo escarpado del terreno y los caminos rudimentarios seguramente contribuyeron a que fuera conocida sólo localmente. ${ }^{1}$ Algunas crónicas mencionan que fue utilizada como escondite durante la guerra de Independencia; se asegura que Vicente Guerrero ocultaba armas y municiones en su interior y que era un enclave importante para la guerrilla que comandaba (Matabuena, 2008, p. 31). Si bien es probable que así haya sucedido, lo cierto es que no se identificaron fuentes primarias que lo comprueben.

${ }^{1}$ Al respecto, William Hardy afirmó que "las carreteras en muchas regiones de México, y especialmente en muchas provincias del interior, son simples caminos transitados por caballos y mulas, pero nunca por un coche o una diligencia. Se necesita un gran conocimiento para viajar, y observaciones constantes y discernimiento agudo para distinguir los senderos de una carretera, los caminos que llevan a un rancho o a campos abiertos [...] y hasta los senderos abiertos por los conejos, porque todos ellos se parecen como las dos hojas de unas tijeras" (en Ortiz, 1973). Recuperado de http://revistas.bancomext.gob.mx/rce/magazi nes/510/6/RCE10.pdf

\section{()(1) $\$$}


Las expediciones formales a Cacahuamilpa comenzaron a partir de 1833, después de que Manuel Sainz de la Peña, vecino del poblado de Tetecala, permaneció oculto en el interior de la gruta debido a que era perseguido por herir en una pelea a Juan Puyadi -lo que confirma que se usaba como escondite por los lugareños-. Una vez garantizada su seguridad personal, Sainz de la Peña regresó a Tetecala, en donde dio cuenta de las maravillas que encontró en su magnífico e imponente refugio (Diez, 1967, pp. 91-92). ${ }^{2}$ También se menciona en algunos relatos que el prófugo se ocultó ahí hacia 1827, que al salir le comentó al padre Mucio Valdovinos su hallazgo, y que fue este quien dio a conocer la ubicación de la caverna y así comenzaron las visitas en el antes mencionado año de 1833 (Gondra, 1844, p. 371; Portilla, 1874, p. 2).

A partir de entonces, el deseo de conocer la gruta y su extraordinario decorado dio pie a innumerables expediciones motivadas por interés científico, artístico o simplemente por la curiosidad. Así, el lugar recibió no sólo a viajeros, sino a estudiosos de los fenómenos geológicos, a naturalistas, botánicos y científicos de todo tipo a pesar de las dificultades que representaba viajar hasta ese sitio, dadas las precarias condiciones de los caminos y de los transportes de la época.

Según los primeros relatos de los visitantes, el trayecto implicaba recorrer trechos muy largos y accidentados durante varios días (véase mapa 1). Algunos de ellos describen el camino que había que tomar si se partía de la ciudad de México; se podía ir a caballo o en diligencia hasta el pueblo de San Agustín de las Cuevas, hoy Tlalpan, lo que tomaba más de cuatro horas (Calderón, 1974, pp. 223; Mayer, 1953, pp. 211-216); de ahí se emprendía camino hacia el poblado del Ajusco, "nido de ladrones y de una gran pobreza"

${ }^{2}$ La familia Sainz de la Peña era propietaria de la hacienda de Actopan, y en $1848 \mathrm{Ma}-$ nuel fue nombrado jefe de la fuerza rural del partido de distrito. Además, se encargaba de la protección de las diez haciendas de la zona, incluida su propiedad. En abril de 1856 hubo levantamientos armados en la región y los campesinos quemaron parte de la hacienda de los Sainz de la Peña. Manuel, que había desempeñado el cargo de subprefecto de Tetecala, fue acusado de asesinato en 1855 , y los vecinos pidieron que se le obligara a pagar los daños y perjuicios causados durante su administración. Eso nos habla de que Sainz tenía un carácter violento, como lo muestra el episodio de su huida y su escondite en la gruta, y las acusaciones antes mencionadas (Reynoso, 2005, pp. 74-75, 77). La hacienda de Actopan fue vendida por el hijo de Manuel Sainz de la Peña, del mismo nombre, a los dueños de la hacienda San Gabriel, Concepción de la Torre de Amor y su esposo, Emmanuel Amor, en 1891 (Toussaint, 1997, p. 240). En cuanto al desempeño de los propietarios de las haciendas como protectores de las mismas, desde 1849 las autoridades gubernamentales conminaron a los hacendados a combatir el bandolerismo y las continuas rebeliones indígenas que amenazaban sus propiedades, por lo que acordaron organizar sus fuerzas entre los mismos trabajadores (Huerta, 1993, pp. 138-141).

\section{()(1) $\$$}




\section{Mapa 1. Ubicación del hoy Parque Nacional Grutas de Cacahuamilpa}

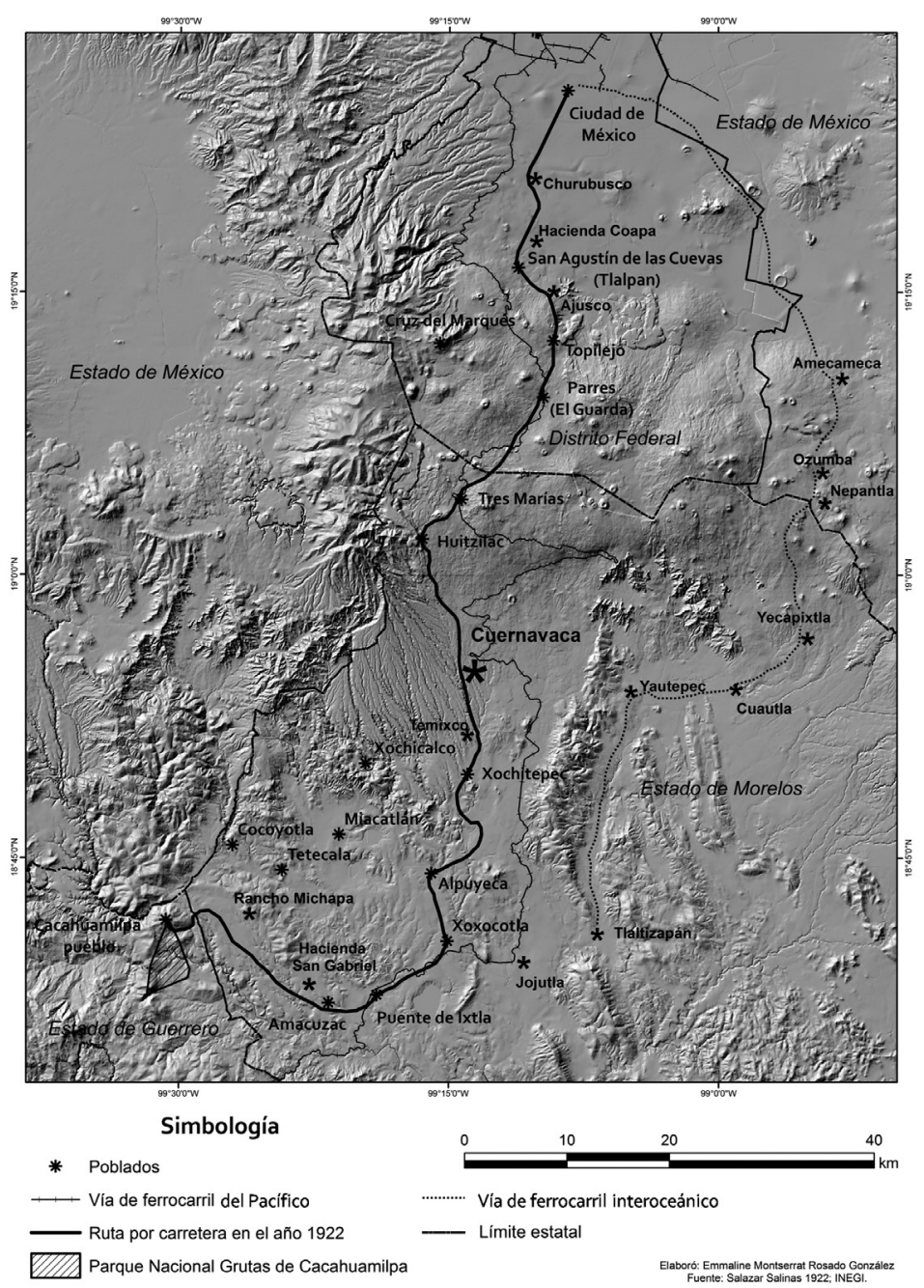

Se muestran las líneas de ferrocarril y la carretera existente en 1922. Los poblados que se indican están referidos en las distintas reseñas decimonónicas consultadas para que el lector ubique los distintos tramos de la ruta seguida por los viajeros, ya que no existían carreteras a partir de la ciudad de Cuernavaca, ni siquiera había caminos rudimentarios, y los viajeros llegaban a la gruta por distintas veredas o a campo traviesa.

Fuente: elaboración de Emmaline Rosado González.

\section{(이요 $(2$}


(Calderón, 1974, pp. 223-249; Mayer, 1953, pp. 216-218). La siguiente parada era Topilejo, "lugar interesante por determinar el punto más elevado del camino" y desde el que podía observarse un hermoso panorama del Valle de México. Se seguía subiendo hasta la Cruz del Marqués, y entonces comenzaba el descenso hacia tierra caliente (Mayer, 1953, pp. 219-221). A decir de Ángel Calderón de la Barca (2012), a la sazón ministro de España en México, quienes se aventuraban a recorrer el tramo entre la capital y la vecina ciudad se las veían frecuentemente con bandas de asaltantes, y el descenso hacia Cuernavaca hacía sentir a los viajeros que bajaban "volando y saltando como pelotas en un cofre" (p. 178). Es claro que no todos disfrutaban el trayecto.

En tierra caliente había posadas para recibir a los visitantes, aunque también se acostumbraba alojarse en las haciendas de los alrededores (Mayer, 1953, pp. 222-223). El viaje continuaba al siguiente día, de madrugada, para evitar el fuerte calor del mediodía, y después de varias horas a lomo de caballo, a campo traviesa, se llegaba a alguna hacienda cercana a la gruta, por ejemplo, Miacatlán. Al atardecer el trayecto continuaba hacia Tetecala, en donde algunos viajeros pasaban la noche (Mayer, 1953, pp. 246-249) o se podía seguir cabalgando hasta llegar a la hacienda de Cocoyotla -ubicada a unos quince kilómetros de la gruta- en donde también se podía pernoctar. Según Calderón y su esposa, que se alojaron ahí en 1840, al dueño de esa hacienda no le hacía muy feliz el hecho de que su casa estuviera en el camino de la gruta, y maldecía "la curiosidad de los que iban a la cueva y hacían de su casa una posada” (Calderón, 2012, p. 180). Por su parte, madame Calderón (1974) decía al respecto que al señor Antonio Silva "no le gusta[ba] que su casa pued[ier]a convertirse en una posada para cuantos la soliciten" (p. 232). Sin embargo, Brantz Mayer (1953, pp. 248-249), quien también estuvo ahí en 1842, habló de su propietario en los mejores términos: afirmó que les ofreció un almuerzo y los llevó a recorrer su huerto de naranjos; al final les mostró la casa y la capilla. En el poblado aledaño se podía pasar la noche en casa de alguno de los habitantes del lugar, que también solía servir de guía, y en la madrugada se emprendía el descenso a Cacahuamilpa. Es decir, el viaje que hoy en día se hace en poco más de dos horas, en la primera mitad del siglo xix llevaba de cuatro a cinco días.

La primera noticia documentada de la existencia de la gruta fue publicada en 1836 como un comentario en una nota a pie de página en la obra de Carlos María de Bustamante (1836), Mañanas en la Alameda, en donde hizo referencia a un manuscrito del "reconocimiento hecho de la famosa Caverna de Cacahuamilpa" (t. II, p. 33), y formuló votos por que se tradujera del fran-

\section{()(1) $\$$}


cés y se diera a conocer al público. El Calendario de las Señoritas Megicanas para el año de 1838 fue el primer medio impreso en donde se publicó una descripción de la caverna. Si bien el artículo no tenía firma, Isidro R. Gondra (1844) se la atribuyó años más adelante al hacer una aclaración sobre el texto en el Liceo Mexicano.

El artículo del Calendario se basó en las descripciones verbales de Jean Baptiste Louis, segundo barón de Gros, diplomático y artista plástico de origen francés que llegó a México a mediados de 1832, fue encargado de Negocios y primer secretario de la Legación Francesa; durante su estancia en nuestro país recorrió varios estados y entre 1834 y 1835 llevó a cabo dos recorridos por la gruta de Cacahuamilpa. En la segunda visita acompañó a Gros el barón René de Pedreauville, como parte de la comisión formada por el gobierno para hacer un reconocimiento de la caverna; este redactó un manuscrito con el resultado de la excursión que, al parecer, fue utilizado para escribir el texto del Calendario (Fossey, 1844, pp. 252-255). ${ }^{3}$ En la primera visita de Gros, le sirvió de guía Manuel Sainz de la Peña, el "descubridor" de la gruta, como se mencionó antes (Romero, 1953, p.6). En la segunda, lo acompañaron Manuel Velázquez de la Cadena, el antes mencionado Pedreauville, Ignacio Serrano, litógrafo, catedrático de la Academia de San Carlos y dibujante de la expedición, además del ministro francés, M. Deffaudis; el ministro de Prusia, barón von Geroldt, el señor Da Ponte Ubero y, nuevamente, Sainz de la Peña. Como fruto de esta segunda visita, el barón de Gros pintó un cuadro de la entrada de la caverna que se conserva hasta nuestros días, y del que Manuel Romero de Terreros (1953) dice que es una de sus pinturas más importantes en la que interpreta "a maravilla una de las más estupendas obras de la naturaleza” (pp. 15-17) (véase imagen 1).

${ }^{3}$ El manuscrito del Barón de Pedreauville sirvió para hacer las primeras descripciones de la caverna, pero nunca fue traducido ni publicado. Sí se publicó una breve descripción de la visita del barón de Gros en una compilación de documentos del Archivo de la Comisión Científica de México (Bonet, 1998, p. 85; Flores, 1909, t. vi, p. 111; Gros, 1865, pp. 143-144). En las minutas de la primera sesión del Instituto Nacional de Geografía y Estadística de la República Mexicana, celebrada el 26 de octubre de 1838, se mencionó como una donación hecha al Instituto un "Extracto de la relación de un viaje a la caverna de Cacahuamilpa, ejecutado en 1835 (manuscrito)" (Boletín, 1839, p. 51). Aunque se realizó una búsqueda exhaustiva del documento en la biblioteca de la hoy Sociedad Mexicana de Geografía y Estadística, no fue posible ubicarlo.

${ }^{4}$ El cuadro del barón de Gros se exhibe actualmente en el Museo Soumaya de la ciudad de México.

\section{()(1) $\$$}




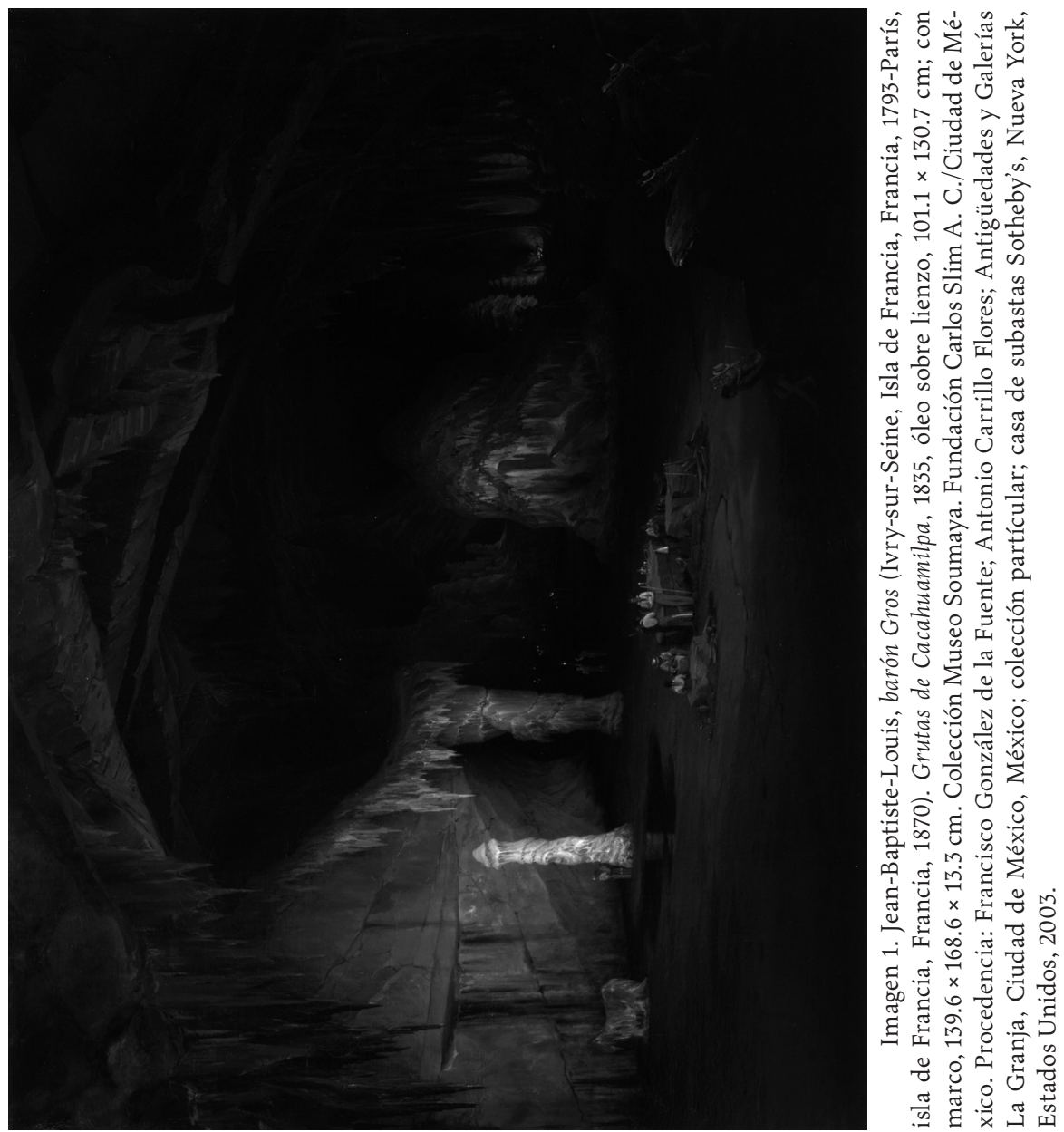

\section{(ㄷ)(1) $(8$}


El texto basado en la visita de Gros a la gruta fue reproducido por diversos medios impresos de la época a partir de su publicación. La primera transcripción fue en el Semanario Pintoresco Español en 1838, en el mismo año en que se publicó la reseña en el Calendario de las Señoritas Megicanas. El que se documentara la existencia de esa maravilla natural en una publicación española es muestra del auge que tuvieron en el siglo xix los relatos de viaje y las expediciones científicas y responde claramente a los intereses de la época; asimismo, el gusto por lo desconocido contribuyó a que nuestro país fuera un destino común para europeos con afán de conocer sitios extraordinarios o exóticos (Ramírez, 2013, pp. 114-136).

Por otra parte, muchos relatos de viaje se escribían para satisfacer las necesidades de información y divulgación de estadunidenses y británicos -quienes sentían una rivalidad apenas disimulada frente a Hispanoamérica en general, y a México en particular-. De ahí que la caverna de Cacahuamilpa se convirtiera en uno de los sitios más visitados por viajeros tanto del nuevo como del viejo continente, y su fama fue creciendo a medida que las noticias sobre su magnificencia y su belleza se difundieron de boca en boca, así como en publicaciones periódicas y diarios de viajeros (Ortega, 1953, pp. 114-136).

Tal fue el caso de madame Frances Calderón de la Barca, ya antes citada, esposa del primer embajador español en México, quien llegó a nuestro país el 18 de diciembre de 1839 y permaneció en él "dos años y veintiún días". Durante su estancia escribió 54 cartas, casi todas ellas sobre diferentes aspectos de la vida cotidiana, que forman su libro La vida en México. Entre sus detalladas descripciones de distintos aspectos del México de entonces, no faltó una carta describiendo con lujo de detalle la expedición que realizó a la gruta; escribió sobre el camino, lo que observó durante el recorrido dentro de la misma y diversas impresiones de su visita al lugar (Calderón, 1974). Los Calderón fueron recibidos en un pequeño rancho cuyo propietario, Miguel Benito, les sirvió de guía (Fisher y Hall, 1966, p. 385).

Para visitar el interior llevaban "veinticuatro grandes antorchas de pino", y recorrieron los diversos salones guiados por velas de cera que fueron colocadas en algunos de los monumentos de piedra para que pudieran encontrar el camino de regreso. A la salida los abordó un alcalde que llevaba una carta dirigida "Al señor comandante de esta caravana de gente", con la intención de saber quién les había autorizado entrar a la cueva. Ángel Calderón (2012) envió una nota explicando que era el ministro español, pero el alcalde, molesto por el desacato a su autoridad, prohibió a Miguel Benito que llevara extranjeros a la gruta, lo que "era muy duro para el pobre viejo que [solía]

\section{(1)(1) $\$$}


ganar algunas monedas de vez en cuando sirviendo de guía" (p. 181). Por lo demás, la visita fue un éxito, y Frances quedó tan impresionada, que escribió

un día llegará, sin duda, en que esta gruta será un lugar de atracción y se tomarán providencias para hacer menos peligroso su acceso, aunque, mientras, esto constituye uno de sus más mayores encantos. Pero su recuerdo queda estampado en la mente como amoroso sueño. Mas como el Niágara, indescriptible; quizá sea aún más difícil dar una idea de esta creación bajo la tierra que del Emperador de las cataratas, pues nada existe que pueda compararse con esta gruta (Calderón de la Barca, 1974, p. 238).

Por su parte, Brantz Mayer (1953, pp. 250-252), secretario de la legación estadunidense entre 1841 y 1842, plasmó sus impresiones de viaje en su libro México, lo que fue y lo que es, y describió con gran detalle el camino a la caverna. La noche anterior a su exploración, Mayer y su grupo se quedaron en el rancho de Michapa, en una choza de indígenas "de barro y cañas entrelazadas", en donde fueron recibidos "con gran cordialidad" por Miguel Benito, en donde pasaron "una velada [muy] agradable". Benito era el mismo personaje que recibió a los Calderón, y quien acompañó a Mayer a la caverna, lo que demuestra que la prohibición de llevar visitantes extranjeros no fue muy severa. Sin embargo, antes de llegar a las inmediaciones de la gruta, se encaminaron hacia la aldea de Cacahuamilpa, en donde tuvieron que entrevistarse con el alcalde para obtener una "licencia" para entrar al monumento natural, lo que sorprendió mucho a Mayer, dado que él y sus acompañantes tenían "pasaportes del Gobierno Mexicano para ir a donde bien [les] pareciese". Cuando el alcalde y su secretario examinaron los permisos, le comunicaron a Mayer (1953) que:

Los señores desean visitar la cueva, y tienen permiso de los alcaldes y jefes de México para ir a donde les pareciere conveniente; todo eso es verdad; pero esa libertad no se refiere a la cueva de Cacahuamilpa, porque dicha cueva está bajo tierra, y el pasaporte no habla sino de lo que está encima. Los señores tienen que obtener licencia del prefecto de aquí, y además, han de pagar para que se la den (p. 252).

Sobra decir que todo el grupo tuvo que pagar, y llama la atención que desde fechas tan tempranas a partir del "descubrimiento" de la caverna, los lugareños ya cobraban por visitarla. Finalmente partieron rumbo a su desti-

\section{(ㅇ)(1) $(3$}


no con doce o trece indios contratados por el anfitrión para servir de guías, cargados con "teas y antorchas para encenderse dentro". Para llegar a la gruta era preciso descender una hondonada por un sendero muy empinado, $\mathrm{cu}-$ bierto de arbustos y maleza, y trepar por peñas y salientes de roca. Como el mismo Mayer (1953) dice,

mas cuando estábamos [...] a vista de la entrada de la cueva, nos impidió el paso un gran saliente de roca que formaba ángulo agudo por el cerro [...] debajo se abría un precipicio casi vertical y de doscientos pies de profundidad; para asirnos no teníamos más que la pelada superficie de la roca y unas cuantas enredaderas que crecían en las grietas del despeñadero [...] Los indios de pies descalzos lo cruzaron con agilidad felina y sin dificultad los de nuestro grupo que llevaban zapatos; más para mí, que llevaba un par de botas para la lluvia, de suelas gruesas, y que no soy muy firme de cabeza para andar al borde de precipicios, me resultó la cosa en extremo ardua. Con todo, asiéndome a las enredaderas, logré salir del paso, aunque en forma poco airosa (p. 254).

Una vez salvados los obstáculos naturales, los excursionistas llegaron a la entrada de la cueva. Para explorarla dejaron una cuerda amarrada en alguno de los primeros salones, con el fin de no perderse en medio de la densa oscuridad que les inundó en cuanto perdieron de vista la entrada. Brantz Mayer (1953, pp. 254-257) recorrió únicamente la parte más accesible de la caverna, ya que varias secciones del camino estaban tapadas por trozos de estalagmitas, tal como él mismo lo narra.

Dado el auge de las visitas a la caverna, en 1844 se reimprimió en el Museo Mexicano el artículo publicado en el Calendario de las Señoritas Megicanas, aunque con modificaciones y notas añadidas de quien lo firmó con las iniciales M. C. Por su parte, en el Liceo Mexicano de ese mismo año se incluyó una nota de Isidro Gondra (1844) en la que aclaró al público lector que el texto citado era de su autoría, y que diversas imprecisiones añadidas al original daban pie a malos entendidos de los que él podía ser responsable involuntario, ya que se prestaban a creer que la mano del hombre había modificado esa maravilla natural. Por lo demás, la intención de Gondra al escribir sobre la caverna, según sus propias palabras, "no era dar una descripción formal y científica de Cacahuamilpa, sino hacer un extracto ligero de la que tenía hecha [...]; un calendario para las señoritas exigía más poesía descriptiva que investigaciones geológicas". En efecto, el tono de los primeros textos sobre la

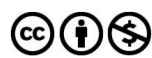


caverna, y que fueron fruto de diversas exploraciones hechas en esos años, fue siempre ligero: descripciones que estaban lejos del rigor científico, ya que se trataba de relatos que buscaban entretener y estimular la imaginación de los lectores.

Por otra parte, debido al incremento de visitantes a Cacahuamilpa, en 1847 Francisco Modesto Olaguíbel, gobernador del Estado de México, dictó la orden de que los excursionistas sólo podrían entrar con un permiso del prefecto de Distrito. La intención de dicha medida era proteger la gruta de la depredación provocada por quienes la visitaban. También ordenó que se cobrara un dólar por cada visitante, y que ese dinero se usara para mantener el camino en buenas condiciones, y para sostener las escuelas de la localidad. Sin embargo, en 1853, durante la última administración de Antonio López de Santa Anna, se derogó dicha orden y se dispuso que hubiera un conserje encargado de cuidar el acceso, y que la entrada fuera libre. No obstante, esa medida sólo estuvo vigente unos cuantos meses, ya que en 1854 la rebelión de Ayutla propició la caída de Santa Anna. A partir de entonces, ningún gobierno se preocupó formalmente por la suerte de la gruta, sino hasta la década de los noventa, cuando, como se verá más adelante, se convirtió en un fruto codiciado por los inversionistas (Mexican National Comission, 1904, pp. 14-15).

Los primeros textos dedicados a la caverna, de carácter meramente descriptivo, sin afán científico, son notables porque sus autores visitaron el sitio en una época muy agitada de la historia de México, en medio de una gran inestabilidad política y del asedio de potencias extranjeras. Y, no obstante, es evidente el afán de los hombres públicos decimonónicos de fomentar la difusión de las maravillas naturales mexicanas, así como el interés de viajeros extranjeros por conocerlas a pesar de los problemas internos del naciente país. Incluso, Marcos Arróniz (1858) menciona que en los años de la invasión estadunidense, varios soldados del país vecino visitaron la caverna y dejaron sus firmas en sus muros. También relata que visitó Cacahuamilpa en dos ocasiones: en 1851 acompañado de Antonio Gallardo, Jorge Icaza, Agustín del Río y Francisco Zarco, y en 1853 fue con "los señores Cuéllar y Argándar, de manera que podemos hablar como testigos oculares de sus bellezas magníficas, que han dejado en nuestros sentidos una impresión profunda que no ha bastado a borrar ni el tiempo con su hálito destructor" (p. 258). Así, ni la guerra, ni los problemas políticos, ni las dificultades impuestas por la topografía y la inseguridad de los caminos desanimaron a los visitantes para conocer la cada vez más famosa gruta.

\section{()(1) $(3$}




\section{LA GRUTA DE CACAHUAMILPA: TEMA CIENTÍFICO, LITERARIO Y PERIODÍSTICO (1850-1879)}

Durante la segunda mitad del siglo xIx Cacahuamilpa siguió siendo un destino frecuente de científicos, literatos y turistas, y precisamente en 1850 se publicó el primer escrito de corte científico sobre la gruta en el Boletín del Instituto Nacional de Geografía y Estadística (1839-1850, pp. 59-68). El artículo anónimo, atribuido después a Joaquín Velázquez de León, apareció también en 1855 en el Diccionario Universal de Historia y de Geografía, obra coordinada por Manuel Orozco y Berra, y el 9 de febrero de 1882 en el periódico El Minero Mexicano, como un homenaje póstumo al autor de dicho texto.

Velázquez de León, ingeniero, catedrático y director del Colegio de Minería, así como reconocida figura política de su tiempo, fue socio fundador del Instituto Nacional de Geografía y Estadística. En el Boletín del Instituto publicó diversos trabajos sobre geología, entre ellos uno dedicado a Cacahuamilpa. En dicho artículo criticó el tono de lo que hasta entonces se había escrito sobre el monumento natural, e inició su escrito afirmando:

No sabemos por qué fatalidad casi todas las descripciones de uno de los grandiosos monumentos geológicos de que puede envanecerse el Estado de México, en su ya famosa caverna de Cacahuamilpa, participan de un estilo más o menos aterrador y excesivamente poético, que produce en unos de sus lectores el pavor, y deja en otros las impresiones de una imaginación acalorada extraviándose fuera del camino de la verdad y de la filosófica observación (“La caverna de Cacahuamilpa", 1850, p. 59).

Así, Velázquez trató de hacer una descripción de tipo geológico y quiso dejar de lado las narraciones fantásticas sobre las formaciones calizas. Escribió su artículo después de una visita a la gruta que se llevó a cabo el 25 de febrero de 1846, época en la que fungía como miembro de la junta de gobierno de la Academia de San Carlos. ${ }^{5}$

${ }^{5}$ En 1843, mediante un decreto presidencial -y gracias a las gestiones del mismo Velázquez de León, entre otros personajes de la época-, Antonio López de Santa Anna dejó estipulado que para la Academia de San Carlos se solicitarían de entre los mejores artistas europeos, directores de pintura, escultura y grabado; además, se le otorgaría autonomía financiera mediante una lotería. Para cumplir las funciones de director de pintura y escultura, respectivamente, arribaron a México en enero de 1846 los catalanes Pelegrín Clavé y

\section{()(1) $\$$}


Velázquez de León afirma que recorrieron la caverna por espacio de siete horas y media, con la intención de llegar hasta los confines del sitio. Pudieron reconocer toda la galería y comprobaron que no había ningún río que atravesara la cueva, y que los monumentos colosales que hay en los últimos salones podían rodearse y volver al mismo camino que los condujo desde la entrada, es decir, confirmaron que la única salida era por donde habían accedido a la gruta. También dieron cuenta del difícil camino, por "los grandes y separados peñascos que a diversos niveles forman un pavimento escabroso y resbaladizo en muchas partes, en razón de la arcilla humedecida que los cubre, principalmente ya al concluir la vuelta para volver a encontrar el cañón principal" ("La caverna de Cacahuamilpa", 1850, p. 62). Hoy en día pueden verse en uno de los últimos salones los nombres de Velázquez de León y sus acompañantes, labrados en la roca, una prueba irrefutable de su presencia en el lugar (véase imagen 2).

Unos años después, luego de su visita con Marcos Arróniz, Francisco Zarco (1852) escribía en El presente amistoso dedicado a las señoritas mexicanas: "[...] yo he querido buscar algo nuevo, algo a lo que no estuviera ya acostumbrado, y por eso he descendido a lo que podemos conocer de las entrañas de la tierra, a la caverna de Cacahuamilpa, abierta en las montañas por la mano de Dios, para presentar al hombre una muestra de su poder y del orden asombroso de sus obras" (t. III, p. 432).

Así, el texto de Zarco volvió al tono que tanto había criticado Velázquez de León: un relato cuyo único fin era entretener, y no describir ya no digamos científicamente, sino al menos detalladamente las formas de la caverna. Por su parte, Arróniz (1858) afirmó en su texto Manual del viajero en México, que "no hay viajero distinguido que visite la República, que no vaya a rendirle el homenaje de su admiración, consagrándole su pluma para revelar sus maravillas" (p. 258). En ese relato se describe un hecho que quedó consignado desde el primer texto, el del Calendario de las Señoritas Megicanas (1838), en donde se explicó que los exploradores encontraron un esqueleto

Manuel Vilar, y acompañaron a Velázquez de León en dos excursiones a Cacahuamilpa (Bablot, 1997, p. 178; Rodríguez, 2010, pp. 203-216). En cuanto a los Tangassi, eran dueños de Tangassi Hermanos; llegaron a México en la década de los cuarenta y se encargarían, entre otras obras, de los monumentos a los Héroes de 1847 en Churubusco y Molino del Rey, inaugurados ambos en 1856. En 1868 presentaron una exposición en los altos del Teatro Nacional con sus piezas más destacadas, importadas de su taller en Volterra, que se pusieron a la venta para adornar las casas de "la gente de buen gusto" (Gutiérrez, 2011, p. 223; Rodríguez, 1997, pp. 136-137).

\section{()(1) $\$$}




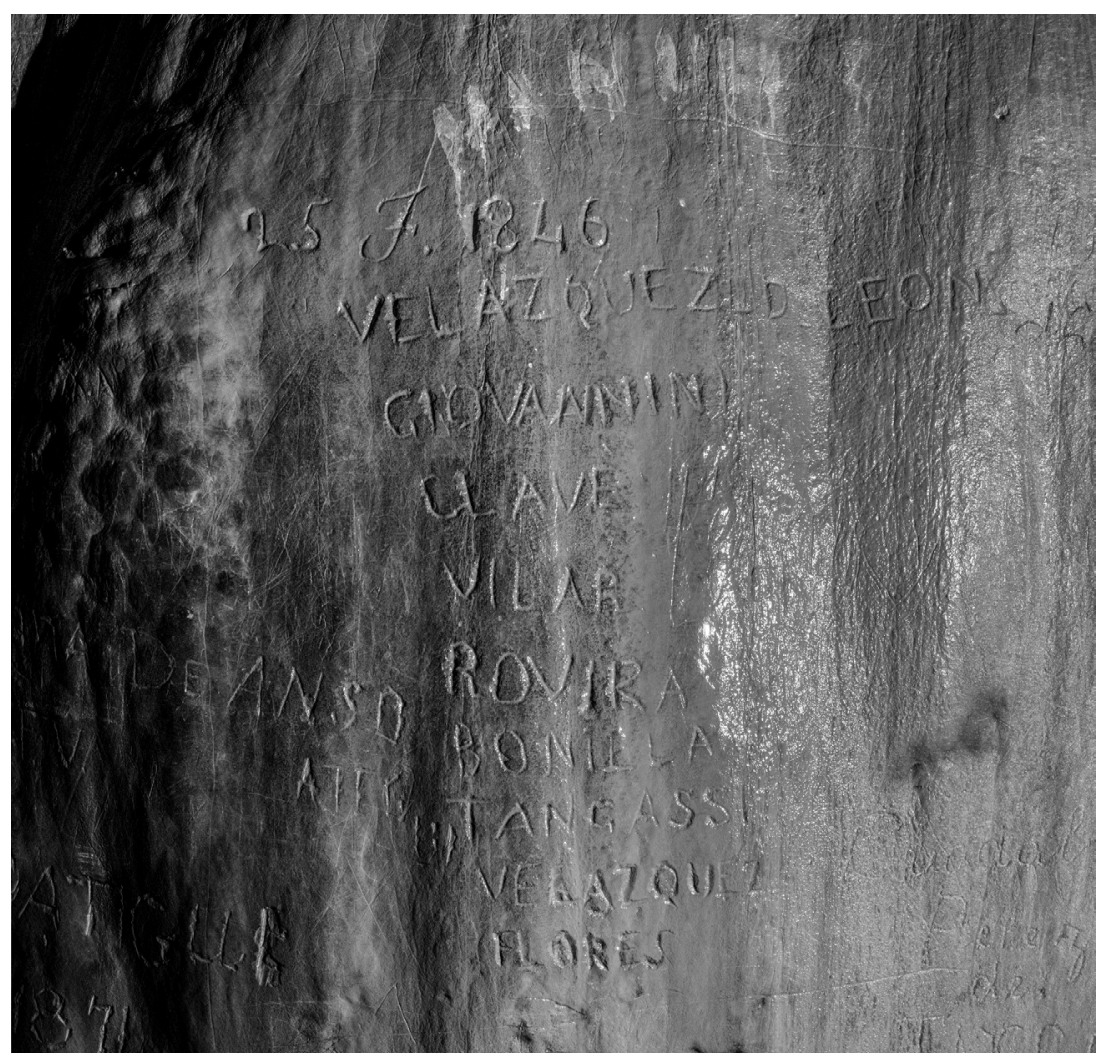

Imagen 2. Fotografía del grabado de 1846, testimonio de la visita de Joaquín Velázquez de León y acompañantes. (2013).

Foto: cortesía de Felipe D. Guzmán Gómez-Aguado <www.felipedguzman.com>

humano cuyo cráneo ya tenía concreciones calcáreas, y una vasija a su lado. El hallazgo se repitió en los textos subsiguientes, lo que sirvió para alimentar toda suerte de teorías sobre el personaje y las condiciones en que encontró la muerte en la soledad de la gruta. Pero Arróniz (1858, p. 261) le agregó otro detalle: que el esqueleto humano estaba acompañado por los restos de un perro.

En cuanto al origen de ese relato, entre el segundo recorrido del barón Gros, en 1835, y la aparición del artículo en el Calendario, en 1838, tuvo lugar la visita de los miembros de una comisión creada con fines de exploración científica (Gondra, 1844, p. 371). Entre ellos iba Ignacio Serrano -discípulo

\section{()(1) $(9$}


del italiano Caudio Linati, que estuvo en México a fines de la década de los veinte-, para entonces director de Litografía en la Academia de San Carlos, y que también había formado parte de la comitiva de Gros. Ahí realizó doce dibujos de la gruta, mismos que nunca se convirtieron en litografías a pesar de que se anunció en su momento que serían publicadas (Aguilar, 2007, pp. 77-83). Una reseña de esa expedición se publicó el 12 de septiembre de 1864 en el periódico español La América. Crónica Hispano-Americana (pp. 9-11). ${ }^{6}$ Firmado por "X", se mencionaba que el barón Gros encontró el esqueleto de un perro, y en otro salón una especie de altar con una vasija rota. En esa tercera visita, los exploradores querían llegar más lejos de lo que había llegado Gros, pero Serrano se negó a continuar, pues aseguró que con lo visto era suficiente para hacer los dibujos de la gruta que le había pedido el "Supremo Gobierno". "X" narra que el grupo decidió seguir adelante y ahí encontró, en un salón contiguo, un esqueleto humano en posición fetal, con calcificaciones en el cráneo. El macabro hallazgo hizo que abandonaran la exploración y salieran de la caverna en donde habían permanecido tres días. Así, se mezclan las dos narraciones y en el relato del Calendario (1838) se mencionó el esqueleto humano, más no el perro. Algunos años después del artículo de Arróniz comenzó a hablarse de un explorador que en los años cuarenta se perdió en la cueva, y cuyo perro salió ladrando de la gruta para llamar la atención de alguien que pudiera rescatar al amo. Sin embargo, como nadie acudió, regresó a morir junto a su dueño. Incluso, se dijo que el visitante extraviado era un inglés. Así, a fines del siglo xix esa historia quedó fijada en el imaginario popular, y se repite hasta hoy en día en las visitas a la caverna. Este es un ejemplo de cómo se construyen los relatos que nutren el imaginario popular, y que en el caso de Cacahuamilpa son numerosos.

Como es evidente, a lo largo de la segunda mitad del siglo xix la cueva siguió siendo un destino atractivo para turistas nacionales y extranjeros, para artistas, políticos, militares, literatos y científicos, y por lo mismo, comenzó a extenderse el interés por conservar en buen estado ese monumento natural. Así, en la sesión de la Sociedad Mexicana de Geografía y Estadística del 4 de junio de 1858, se pidió al "supremo gobierno" que vigilara la conservación de la "Gruta admirable de Cacahuamilpa", ya que se sabía que "pocos son los que entran a la cueva que no salgan con algunos pedazos de

${ }^{6}$ En 1886 apareció otra crónica sobre la gruta de Cacahuamilpa en el mismo periódico, en una época en que el país buscaba inversionistas para la construcción del ferrocarril y de caminos más transitables. Crónica Hispano-Americana, 28 de enero de 1886, pp. 14-15.

\section{()(1) $(9$}


estalactitas". Se decía que si bien la entrada a la gruta no podía impedirse, tampoco era tolerable que se hicieran disparos que producían la caída de las formaciones rocosas. Podían permitirse lanzamientos de cohetes de luz que no produjeran detonaciones, pero no las explosiones, lo que era práctica frecuente. También sobre la degradación de que era objeto la caverna, Brantz Mayer (1953) narró, en 1842, cómo el propietario de la hacienda de Cocoyotla, en donde se hospedó, le mostró "el interior de la linda iglesia, donde había hecho levantar pedestales para varias imágenes de santos, con las estalactitas de una caverna cercana" (p. 248), lo que es evidencia del saqueo. Al respecto, unos años más adelante Eugenio Landesio (1868), profesor de la Academia de San Carlos, al hablar sobre las estalagmitas de la caverna que tienen forma de troncos de palmera, mencionó que "hermosos trozos de esta concreción adornan la capilla de la hacienda de Cocoyotla” (p. 16).

Se dice que en la época de la Reforma, el entonces presidente Ignacio Comonfort exploró la caverna, pero no hay más pruebas que los dichos de viajeros que posteriormente visitaron el lugar y aseguran haber visto su firma en alguna de las paredes. De lo que no hay duda es de que la gruta siguió siendo un destino muy atractivo, como lo demuestra el hecho de que en tiempos del segundo imperio la emperatriz Carlota visitó el lugar, como ella misma lo narra en una carta que escribió a José María Gutiérrez de Estrada, uno de los promotores de la llegada de Maximiliano de Habsburgo a México. Carlota (1866) acudió a "la bella gruta" en mayo de 1866, la calificó como "una de las maravillas de este continente", y afirmó haber escrito su nombre "aún a mayor distancia de la en que se encuentra el de Comonfort y varios otros, no queriendo que el Imperio quede atrás en este terreno como en ningún otro" (p. 3). A decir de José Luis Blasio (1903), secretario privado de Maximiliano de Habsburgo, este no acompañó a la emperatriz a la visita. Ella fue recibida con gran pompa en la hacienda de San Gabriel y de ahí cabalgó hasta la caverna. Según el relato de Blasio (1903) "su Majestad, teniendo en cuenta los numerosos peligros que abundan al penetrar a esas cavernas, no llegó hasta el último salón [...] sino que se detuvo en uno, donde aún pueden los viajeros leer una inscripción que les recuerda el paso de la emperatriz por ese lugar" (pp. 197-198).

En enero de 1868, trece años después de su llegada a México, Eugenio Landesio realizó una expedición a la gruta. Con motivo de esa excursión y de su visita al Popocatépetl, escribió un libro en el que relató sus experiencias. Después de afirmar que "hasta en Roma resonaba en mis oídos la reputación de la afamada y extraordinaria caverna de Cacahuamilpa” (Landesio, 1868,

\section{(이) $(3$}


p. III) narró, como ya lo habían hecho muchos otros viajeros, las peripecias del camino entre la ciudad de México y Cacahuamilpa. Landesio y sus acompañantes salieron por la garita de San Antonio Abad, pasaron por Nativitas y la hacienda de los Portales hasta llegar a Tlalpan. De ahí comenzaron la subida hacia Topilejo y llegaron a el Guarda, un pueblito en el cerro del Ajusco, en donde almorzaron "en una pobre y triste choza, bastante mal y bebiendo pulque agrio". Al bajar hacia Cuernavaca, pasaron por Huitzilac y Tlaltenango, y finalmente llegaron al anochecer a aquella ciudad. Dos días después continuaron su camino y pasaron por Temixco rumbo a Miacatlán, en donde pernoctaron. Al día siguiente llegaron a Cocoyotla (véase mapa 1). La mañana siguiente continuaron su ruta y después de atravesar barrancos y arroyos, y de subir montañas "pedregosísimas" se encaminaron al poblado de Cacahuamilpa, en donde pagaron por los derechos de entrada a la caverna $y$ al fin llegaron a su destino (Landesio, 1868, pp. 1-11). Una vez en el interior de la cueva, Landesio (1868) pudo observar con lujo de detalle las peculiares formaciones, y dejó todo bien documentado en su texto. Cabe destacar su preocupación por el maltrato y la depredación a que estaba expuesta:

Antes de pasar a otra cosa, es preciso observar que cada visita que se hace a la caverna, cuesta un deterioro grande a las estalagmitas y estalactitas, puesto que se agrega una cantidad de naturales con el fin de romper las concreciones, y vendérselas a los visitadores al salir de la misma. Cuando yo fui, entró con nosotros una falange de estos señores, los que en lugar de vigilar e impedir la destrucción, destruían ellos mismos por do quiera las concreciones más finas e interesantes, y haciendo las piedras informes oficio de escoplo y de martillo, destruían mucho para conseguir poco. Otros lanzaban pedradas a las estalactitas que colgaban de las bóvedas, con el fin de romper y hacer caer un pedazo de ellas [...] Ojalá se cerrara el ingreso de este museo subterráneo a todos los profanos, que sólo entran animados del espíritu vandálico de la destrucción (p. IV).

Así, nuevamente se hacía notar que era necesario proteger la caverna de los numerosos visitantes que acudían cada año a conocerla.

Por otra parte, Landesio $(1868$, p. 16) también narró la historia del explorador y el perro, pero ya no se mencionó que fueran esqueletos, sino cadáveres. Y dijo que el del hombre estaba completamente desnudo porque al quedarse sin iluminación por haber consumido sus antorchas, se despojó de sus ropas para prenderles fuego e iluminarse con ellas, aunque de todos

\section{()(1) $\$$}


modos encontró una muerte terrible al no poder salir de la cueva. Es evidente que ese relato, como lo mencionamos antes, se fue transformando a lo largo de los años.

En 1874 Mariano Bárcena, entonces alumno de la Escuela Especial de Ingenieros de México, publicó el libro Viaje a la caverna de Cacahuamilpa; datos para la geología y la flora de los estados de Morelos y Guerrero, resultado de la excursión que realizara a esa localidad. ${ }^{7}$ Como lo hicieran otros viajeros años antes, Bárcena (1874) describió el camino recorrido hasta llegar a la gruta, haciendo énfasis en la descripción de los tipos de roca que iba encontrando a su paso. En su libro menciona que "en una de estas montañas que está situada como a una legua de Cacahuamilpa, se halla la famosa caverna que visitó el Sr. Presidente de la República el día 18 de febrero de este año acompañado de algunas personas entre las cuales tuve la honra de contarme" (p. 7). El autor se refiere a la visita que hizo Sebastián Lerdo de Tejada, hecho que fue muy criticado por la prensa de oposición por considerarse una frivolidad que Lerdo visitara Cacahuamilpa con sus ministros y varios gobernadores, además de ser, según los detractores del presidente, una violación al artículo 84 constitucional que prohibía que el titular del ejecutivo se separara de sus funciones sin motivo grave. Así, se decía en las páginas de El Radical: "desprestigiarse por paseos, por convites, por un viaje a Cacahuamilpa y por ocho días de vacaciones escandalosas [...] cuando el Señor Presidente no puede ver la famosa gruta de Cacahuamilpa más que con los ojos del turista, y no con los del hombre de la ciencia" (Riva Palacio, 1874).

Por su parte, Anselmo de la Portilla (1874) narró en La Iberia los pormenores del viaje que fue considerado un éxito. Dice que al presidente Lerdo lo acompañaba una comitiva de aproximadamente quinientas personas, "entre ellas tres o cuatro mujeres que heroicamente soportaron las fatigas del viaje por la gruta”. De la Portilla mencionó que a su paso por uno de los salones encontraron una cruz hecha con dos palos atados con una cuerda, que marcaban el sitio en donde fue encontrado el esqueleto de un extranjero que murió allí acompañado de "su fiel perro": la leyenda se consolidaba en el imaginario popular. También hizo referencia a la firma de Comonfort, que estaba en una peña, y a la de Carlota, que visitó la gruta, casualmente, el mis-

${ }^{7}$ El 27 de octubre de 1849 se declaró formalmente constituido el estado de Guerrero. Decreto de creación del estado de Guerrero (Carmona, 2014a). El 17 de abril de 1869 se publicó el decreto de creación del estado de Morelos. Se crea el estado de Morelos (Carmona, 2014b). La gruta de Cacahuamilpa quedó ubicada geográficamente en Guerrero, en los límites con Morelos y el Estado de México.

\section{(이요 $\$$}


mo día que Lerdo, pero ocho años antes. Los señores que acompañaban al presidente comentaron que "parece en efecto imposible que una señora haya arrostrado la fatiga y los peligros del viaje por la cueva hasta aquel punto", ya que en varios tramos era preciso entrar a gatas a los salones. Finalmente llegaron al llamado salón de los órganos, el punto más alejado de la entrada de la caverna, y ahí pusieron un letrero con la fecha de la visita, es decir, el 18 de febrero de 1874. En esa excursión también iba el geógrafo Antonio García Cubas (1874), que a su vez escribió un texto dedicado a la gruta, y cuyo final era muy elocuente: "La Sociedad de Geografía y Estadística, atendiendo a la importancia real de esta obra natural [...] debe mandar explorarla y hacer los estudios que la ciencia exige" (p. 162). Como fruto de la promoción que se le hizo a dicha visita, y al parecer siguiendo la recomendación de García Cubas, en un artículo publicado el 27 de marzo en La Iberia, se mencionó que un grupo de filántropos donó 1000 pesos a dicha Sociedad para apoyar la comisión científica que se creó para estudiar la caverna.

En febrero de 1875, exactamente un año después de la excursión de Lerdo de Tejada, fue a Cacahuamilpa un grupo de personas entre las que se encontraba Guadalupe Villegas de Sainz de la Peña, esposa del "descubridor" de la caverna. El motivo de dicha visita era "fijar la nomenclatura de los salones de la gruta, poniéndoles nombres de celebridades aztecas". Por su parte, otra de las visitantes, entusiasmada, "subió a uno de los mausoleos que le adornan, e improvisó unos magníficos versos saludando aquellas maravillas de la naturaleza", según publicó La Iberia el 3 de marzo de ese año. Es decir que Cacahuamilpa seguía siendo noticia en los periódicos, e incluso se organizaban excursiones para alabar su magnificencia. Por otra parte, el plan de bautizar los salones con nombres prehispánicos fue sólo una ocurrencia que no trascendió.

En 1879 la caverna fue noticia nuevamente debido a que la comisión científica encargada de explorarla, en la que participaba Mariano Bárcena, descubrió otra cueva aledaña que fue bautizada con el nombre del entonces gobernador de Morelos, Carlos Pacheco, quien también formó parte de esa expedición. Además, a raíz de unas lluvias intensas ocurridas en los alrededores, se temió que la gruta desapareciera por los hundimientos ocurridos. Esa posibilidad fue desmentida por el ingeniero de minas, Antonio del Castillo, quien envió una carta a la Sociedad de Geografía y Estadística, publicada en El Siglo Diez y Nueve el 27 de octubre, explicando, para tranquilidad general, que la gruta no estaba en peligro.

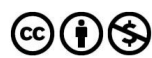




\section{LA GRUTA DE CACAHUAMILPA EN UN PERIODO DE MODERNIZACIÓN Y CRECIMIENTO ECONÓMICO (1880-1910)}

En 1917 Teodoro Iturbide escribió una Reseña descriptiva de la gruta de Cacahuamilpa, en la que se presenta como "explorador de la misma en los años de 1880 a 1900". Dicho personaje fue secretario del Ayuntamiento de Taxco y miembro de la Sociedad Mexicana de Geografía y Estadística, e incluso en una nota de prensa del 16 de febrero de 1895, publicada en El Amigo de la Verdad, se le menciona como "el hombre que mejor conoce la gruta en toda la República”. En su libro, Iturbide (1917) se identificó como "Director General de todas las expediciones o visitas que se hicieron a la Caverna”, y describió con lujo de detalles el viaje de Porfirio Díaz que se llevó a cabo en 1881. La relación de hechos es sorprendente: el autor menciona la construcción de una carretera de $22 \mathrm{~km}$, entre Amacuzac y la gruta, "para comodidad de los viajeros"; asimismo, da cuenta de la construcción de 180 camarotes de madera que "no desdecían al mejor hotel de la capital" para albergar a Díaz y sus invitados, todos los gobernadores de los estados del país y los miembros del cuerpo diplomático. También mencionó que la caverna fue iluminada con 850 focos incandescentes alimentados por "una caldera que movía un dinamo eléctrico", y que en los alrededores se instalaron, según el relato, líneas telefónicas y otras comodidades, entre ellas "salas de billar, dominó y ajedrez, circos, teatros de la legua, maromas, rifas de loza [...] y una inspección general de policía”. A decir de Iturbide (1917), no faltaron, por supuesto, las orquestas, los banquetes y los bailes, y los invitados permanecieron en el recinto veinte días (pp. 55-62). En su relato incluye una historia que involucra al célebre compositor mexicano Juventino Rosas, quien a decir de Iturbide interpretó por primera vez el vals "Carmen", en honor a Carmen Romero Rubio, la entonces prometida de Díaz, quien también formaba parte del grupo (p. 64). Sin lugar a dudas este relato es fascinante y por ello muchos otros autores lo han repetido en diversos escritos. La historia, sin embargo, es falsa; la pieza musical se estrenó en 1893 en ocasión del cumpleaños de Porfirio Díaz y no en Cacahuamilpa, cuando, por otra parte, Juventino tenía apenas 13 años de edad. Asimismo, son falsos o exagerados la mayoría de los hechos que narra Iturbide, aunque han servido para alimentar varios relatos que hoy en día son repetidos por los guías de la caverna, en la información turística sobre el sitio e, incluso, en investigaciones sobre la gruta (Matabuena, 2008, p. 31).

\section{()(1) $\$$}


En marzo de 1881, en efecto, se llevó a cabo una visita a la caverna de Cacahuamilpa, organizada por el entonces gobernador de Morelos, Carlos Quaglia, y a la que fueron importantes personalidades de la época, entre ellas Porfirio Díaz, entonces ministro de Fomento; Ignacio Mariscal, de Relaciones Exteriores, y Gerónimo Treviño, de Guerra; todos miembros del gabinete de Manuel González. También iba con ellos el ex gobernador de Morelos, Carlos Pacheco, que unos meses después sustituiría a Díaz en la cartera de Fomento. El laconismo de la mayoría de las notas de prensa de la época contrasta con el relato de Iturbide, y en gran número de estas se menciona que la expedición no salió tan bien como se hubiera esperado, ya que "algunos accidentes inesperados contrariaron a los viajeros", según la noticia publicada el 29 de marzo en El Nacional, e incluso Quaglia, "fue atacado de asfixia, encontrándose bastante enfermo", como se afirmó en El Telégrafo el 29 del mismo mes. El gobierno tenía particular interés en esa visita, dado que iban en la comitiva el general Edward Ord, enviado por la Mexican Southern Railroad -que tenía la intención de construir la línea ferroviaria de Texas a la ciudad de México- y Thomas Braniff, conocido empresario llegado a México para trabajar en la construcción del Ferrocarril Mexicano (Ribera, 2012, pp. 17-18); por ello se había dispuesto que por primera vez la caverna fuera iluminada con luz eléctrica. Sin embargo, en otra nota aparecida en $\mathrm{El}$ Nacional el 31 de marzo de 1881, extraída del Correo de Morelos, se aseguró que "los aparatos eléctricos no [habían] funcionado bien, y sólo dieron luz escasa y opaca en los primeros salones, por lo que en los siguientes se hizo uso de luces de bengala, de las que se quemó gran cantidad", lo que causó que el aire de la gruta fuera irrespirable y que varios de los excursionistas presentaran síntomas de asfixia.

Por su parte, en La Voz de México del 3 de abril se publicó una reseña más detallada, en la que se mencionó la comida que se sirvió en el primer salón de la gruta, después de la cual algunos invitados se quedarían a dormir ahí. El consumo de una gran cantidad de bengalas y el uso de una caldera para producir electricidad llenó de humo los salones, lo que causó que varios de los visitantes tuvieran que ser sacados de la cueva cuando ya perdían el conocimiento. No obstante el desafortunado fin de la excursión a Cacahuamilpa, en el periódico The Two Republics, editado en México - pero que estaba dirigido a público angloparlante y tenía evidentes fines propagandísticos-, en la misma fecha que en $\mathrm{La} V \mathrm{Voz}$, se dijo que la expedición había sido todo un éxito, y que la visita a la gruta había terminado con una agradable cena en la que hubo discursos de agradecimiento, especialmente dirigidos al ge-

\section{()(1) $(2$}


neral Ord, un "destacado representante de la gran república de los Estados Unidos”. El autor de dicha reseña evitó mencionar el desafortunado fin de la expedición, seguramente porque lo que se buscaba era promover la visita y hablar del éxito de esta, dado el interés que había entonces por buscar inversionistas para la construcción de ferrocarriles en la república mexicana. En ese sentido, no era casual que a la visita haya ido Carlos Pacheco, quien en 1880 había recibido el nombramiento de "presidente honorario perpetuo" de la Junta Directiva de la Compañía del Ferrocarril de Morelos, constituida tres años antes, y que buscaba dotar a ese estado de una red ferroviaria que comunicara todas sus regiones. Pacheco, por su parte, favoreció a los grandes consorcios ferroviarios extranjeros a costa de los inversionistas locales, ya que él mismo era accionista de la compañía (Crespo, 2011, pp. 544-550).

En 1886 la gruta de Cacahuamilpa volvió a ser noticia, y en tres periódicos - uno español, la Crónica Hispano-Americana, del 28 de enero; y dos nacionales, Municipio Libre, del 30 de enero y el 3 de febrero, y La Patria, del 7 de febrero-, se publicó un texto de Cecilio Robelo sobre la caverna, en el que se describieron los diversos salones que la componen, y se incluyó una lista con los visitantes distinguidos. Es notorio que se hizo énfasis en las tres visitas hechas por Carlos Pacheco, incluyendo la de 1881, cuando "se iluminó la gruta con luz eléctrica”. Y es que precisamente en ese año de 1886 se firmó un contrato entre la Secretaría de Fomento -encabezada por Pacheco- y la Compañía del Ferrocarril Mexicano del Pacífico, para construir una línea que uniera la ciudad de México con un punto intermedio entre Acapulco y Manzanillo. La ruta debía pasar por Cuernavaca y Puente de Ixtla, precisamente el camino que se tomaba para ir a la famosa gruta. No obstante, la obra no se llevó a cabo entonces sino hasta 1892, y fue hecha por otra compañía de capital estadunidense (Crespo, 2011, p. 557).

El 12 de noviembre de 1886 apareció en La Patria la noticia de la fundación de una compañía que se encargaría de organizar "viajes de recreo" a la gruta de Cacahuamilpa, que para tal efecto sería iluminada con luz eléctrica, y tendría guías especializados. Una nota muy similar se publicó al día siguiente en The Two Republics. El 25 de julio de 1888 se volvió a tratar el tema en el periódico Le Trait D'Union, en cuyas páginas se aseguró que el señor José Nosari, empresario italiano radicado en México, había obtenido la concesión del gobierno del estado de Guerrero para explotar la gruta por un periodo de 25 años. Los precios de entrada serían fijados de acuerdo a lo que autorizara el gobierno estatal, y Nosari debía dar al estado 25 centavos por cada visitante. Además, tenía el proyecto de formar una compañía con

\section{(이요 $\circledast$}


capital suficiente para construir un ferrocarril de vía estrecha hasta la cueva. La intención era abaratar los costos del viaje y facilitar que tanto extranjeros como mexicanos pudieran ver "esa maravilla natural".

Sin embargo, ese proyecto tardó algunos años en consolidarse, ya que en 1892 la compañía aún no estaba establecida, como puede deducirse en la reseña de la excursión que hizo Guillermo Beltrán y Puga (1892, p. 6), presidente de la Sociedad Científica Antonio Alzate, ${ }^{8}$ y a la que asistieron, entre otros, el director del Instituto Médico Nacional, Fernando Altamirano Carbajal, y varios de sus miembros, además de un paisajista y un fotógrafo. En total, iban 28 personas. En su escrito, Beltrán (1892) narra que para alumbrarse en su recorrido por la caverna, llevaban

seis docenas de fanales, cuya duración es de cinco minutos, de las cuales tres docenas darían luz roja, y el resto blanca o verde, cuatro docenas de cohetes de luz, entre los que había igualmente rojos, blancos y verdes; seis paracaídas; además de esto se contaba con ocho cintas de magnesio [...] y se acordó que además de esos elementos de alumbrado, llevara cada uno velas de cera (p. 3).

Es decir que para entonces la instalación de luz eléctrica en la cueva todavía no se había llevado a cabo.

A diferencia de otros viajeros decimonónicos, Beltrán viajó en el Ferrocarril Interoceánico, que salía de la estación de San Lázaro en la ciudad de México y llegaba a Jojutla: recorrieron 196 kilómetros en diez horas de viaje. El tren pasaba por Amecameca y Ozumba, desde donde comenzaba el descenso a tierra caliente. En Nepantla cambiaron de tren, y la siguiente parada fue en Cuautla; de ahí se dirigieron a Yautepec y Tlaltizapán, hasta su destino final. Continuaron a caballo hasta San Gabriel, distante 24 kilómetros (véase mapa 1). Al día siguiente, después de seis horas de camino, por fin llegaron al pueblo de Cacahuamilpa, en donde fueron recibidos por

${ }^{8}$ La Sociedad Antonio Alzate fue fundada en 1884 por Guillermo Beltrán y Puga y otros estudiantes de preparatoria. Los fundadores fueron bien acogidos por maestros como Mariano Bárcena. Alfonso Herrera, entonces director de la Escuela Nacional Preparatoria, les dio un espacio en el plantel para que realizaran sus trabajos, en donde pronto comenzaron a formar una biblioteca y una colección de ejemplares de historia natural y de instrumentos científicos. La sociedad posteriormente ocupó varias sedes hasta que el gobierno le asignó la casa ubicada en el número 19 de la calle de Justo Sierra, la que ocupó conjuntamente con la Sociedad Mexicana de Geografía y Estadística. En 1930 fue designada como Academia Nacional de Ciencias "Antonio Alzate". Memorias y Revista de la Sociedad Científica Antonio Alzate. Recuperado de http://www.palaciomineria.unam.mx/eventos/ant_memorias_y_revistas.htm

\section{()ㅜ(1) $\$$}


el coronel Crescencio Rosas, "encargado del gobierno del estado para vigilar la gruta", con quien dispusieron lo necesario para su visita. En la reseña, Beltrán (1892, p. 58) refiere haber encontrado la firma de Carlota de Bélgica y ellos también dejaron una inscripción: Instituto Médico Nacional 1892.

A ese respecto, este autor, como otros antes que él, afirma que cuando Carlota visitó la caverna quiso salir repentinamente porque sintió un gran malestar, y se encontró con un mensajero que traía la noticia de la muerte de su padre, Leopoldo I. Sin embargo, la emperatriz visitó la gruta meses después del deceso del rey de los belgas. Sucede lo mismo que con el relato de la visita de Porfirio Díaz, y con la narración sobre los esqueletos del hombre y el perro: las tres son leyendas -basadas en hechos reales, pero que están mezcladas con fantasía- que se repiten en muchos de los textos escritos sobre Cacahuamilpa, incluso en nuestros días.

Fue hasta 1896 cuando finalmente se fundó la Compañía Balnearia de Ixtapan de la Sal, explotadora de las Grutas de Cacahuamilpa, S. A., año en que ya funcionaban dos ferrocarriles que llegaban a Puente de Ixtla -el Interoceánico y el del Pacífico- (véase mapa 1). El objetivo de esta empresa era la explotación simultánea de las aguas termales de Ixtapan y de la gruta, y especialmente debía "gestionar la concesión de un ferrocarril, de Amacuzac a Toluca", según se publicó el 5 de julio de ese año en La Convención Radical Obrera; es decir, había intereses muy claros en la construcción de esa ruta, y de acuerdo con los afanes modernizadores del régimen porfirista, como se mencionó antes, se impulsaban proyectos de inversión, sobre todo en vías férreas. El director de la compañía fue José Nosari, a quien el poder ejecutivo del estado le otorgó la concesión por 50 años, a prorrogarse otro tanto si el concesionario así lo quería. Al parecer, también existía el plan de hacer un camino para coches, pero la ruta para su construcción era de propiedad particular, lo que impidió la aprobación de dicho proyecto, por lo que los excursionistas se veían obligados "a transitar por una vereda incómoda" (Nosari, 1899 , p. 6). Nuevamente se planteaba iluminar la caverna con luz eléctrica mediante la instalación de "200 luces de arco y 600 incandescentes", así como construir "en el interior de estas un ferrocarril ad hoc, y una carretera desde Cacahuamilpa hasta el punto donde ordinariamente hace escala el Ferrocarril Interoceánico".

En el pueblo de Cacahuamilpa se construyó un pequeño hotel para recibir a los turistas; el pago incluía dos noches de hospedaje y el recorrido por la caverna con guías capacitados. En un inicio, el concesionario de la gruta dispuso las camas en la entrada, es decir, en el primer salón; para ello, en

\section{(이요 $(2$}


1896 se colocaron estaquitas de manera simétrica que servirían para separar los dormitorios; además, se instaló un restaurante y un billar, tal como se narra en la nota del 29 de febrero de ese año en el periódico The Mexican Herald. En esa ocasión viajaron a la caverna diez excursionistas -tres franceses, seis mexicanos y un inglés-y el encargado, a decir de ese medio informativo, se tomó todos los cuidados necesarios para ahorrar a los visitantes cualquier molestia: habilitó los dormitorios en el salón de la entrada y ahí sirvió una excelente cena, después de haberlos llevado a un recorrido por los alrededores. Sin embargo, ese proyecto no prosperó, ya que "a causa de estar en despoblado, habiendo surgido dificultades que no pudo vencer, [Nosari] se retiró para fundar la Compañía Explotadora y radicarse al fin en el pueblo de Cacahuamilpa en donde abrió, y tiene a disposición de los excursionistas, una casa bastante bien servida" (Nosari, 1899, p. 24).

De cualquier manera, el concesionario hizo difusión a su compañía en la prensa en busca de inversionistas, y aseguraba que "con poco dinero, abonado en parcialidades de 25 centavos semanarios, y con reembolso del capital dentro de un plazo corto, el accionista puede asegurar una ganancia de 3 a 6 por 100 durante 30 años, término de la concesión", según noticia del 12 de julio de 1896 en La Convención Radical Obrera.

Para promocionar la Compañía y atraer más visitantes, Elvira Nosari, hija del concesionario de la gruta, escribió un librito titulado Viaje a la caverna de Cacahuamilpa; asimismo, pretendió montar, con la ayuda de su hermana, un "drama patriótico" en el Teatro Nacional, con Cacahuamilpa como escenario, ya que quería, según sus palabras, "a ejemplo de nuestro padre, dar a conocer siquiera superficialmente, la joya más grandiosa que posee nuestro hermoso país". ${ }^{9}$ No fue, sin embargo, un propósito que llegara a su culminación, ya que a decir de la misma Elvira, su padre se quedó sin dinero porque invirtió todo en la compañía, y ella junto con su hermana gastaron sus ahorros en pagar al escenógrafo que hizo varias reproducciones de la caverna. Cuando llegó el momento de cubrir el alquiler del teatro ya no disponían de fondos, por lo que envió una carta al entonces ministro de Economía, José Yves Limantour, en la que lo felicitaba por la intención del gobierno de remodelar el Teatro Nacional para montar en él espectáculos cultos a precios módicos. Seguramente pensaba pedir a Limantour su apoyo

${ }^{9}$ Carta manuscrita de Elvira Nosari a José Yves Limantour. 19 de febrero de 1900. Colección José Y. Limantour. Fondo CDLIV. Segunda serie. Año 1900. Carpeta 11, documento 18365. Centro de Estudios de Historia de México Carso, México.

\section{()(1) $\$$}


para poder montar su drama. Como es sabido, pasó una década y el Teatro Nacional no estuvo listo, de manera que dicha obra nunca se estrenó.

En una iniciativa que parece extraña, por decir lo menos, los accionistas de la Compañía Explotadora pretendieron enviar una reproducción de la gruta de Cacahuamilpa a la Exposición de París de 1900, para ser exhibida en el pabellón mexicano. Según la nota aparecida el 7 de agosto de 1898 en La Convención Radical Obrera, la Secretaría de Fomento pagaría los pasajes de los empleados encargados de montarla y los escenógrafos Jesús y Leonardo Herrera -cuya escenografía se pensó que podría ser usada después en el Drama patriótico de Elvira Nosari-tendrían a su cargo la representación de los "detalles notables del prodigioso lugar”. Esa empresa tampoco llegó a buen puerto, ya que era más costosa y difícil de lo que habían imaginado sus promotores.

Con lo dicho antes, resulta evidente que la Compañía Explotadora fue un proyecto fallido. El 12 de agosto de 1900 apareció otro artículo al respecto en The Mexican Herald, en el que un visitante estadunidense narra su viaje hasta el pueblo de Cacahuamilpa y la frustración que sintió, ya que no pudo visitar la caverna debido a que no contaba con la autorización del señor Nosari, quien era el único que para entonces podía permitir el paso al lugar. A decir del autor del artículo, envió un telegrama a la esposa de aquel para que se le permitiera visitar la gruta, pero no recibió respuesta.

El 29 de mayo de 1905, según nota del Periódico Oficial del Gobierno del Estado de Guerrero, el Congreso guerrerense le retiró a Nosari la concesión con los argumentos de que la legislatura local nunca había aprobado el contrato celebrado por el ejecutivo; que la cantidad de 25 centavos por visitante era irrisoria y ni siquiera valía la pena que alguien se encargara de cobrarla, que la gruta era una maravilla de la naturaleza que podía llevar muchos beneficios a Guerrero, y que no tenía por qué favorecer sólo a una persona. A pesar de que Nosari solicitó un amparo, perdió la concesión, si bien no se sabe la fecha exacta, ya que el 25 de octubre de 1908 The Mexican Herald publicó un extenso artículo con la narración de una visita en la que Nosari acompañó al extranjero que narra sus aventuras en la caverna. Por otra parte, la ruta del ferrocarril nunca se construyó y el número de visitantes a principios del siglo $\mathrm{xx}$ fue exiguo, ya que a pesar de los avances tecnológicos, seguía siendo un trayecto difícil, oneroso y largo, por lo que no se concretó como el gran negocio que se esperaba.

Entre los primeros escritos de carácter científico publicados en el siglo xx está el de Teodoro Flores, de 1908; ese texto sirvió de guía en la excursión organizada por la Sociedad Geológica Mexicana en 1909. Compuesta

\section{(이요 $(3$}


por quince personas, incluido Flores, hicieron el trayecto en el ferrocarril del Pacífico hasta Puente de Ixtla y de ahí se trasladaron al pueblo de Cacahuamilpa (véase mapa 1). El texto de Flores (1909, pp. 93-111), a diferencia de los que se escribieron en años anteriores, trató aspectos históricos, pero sobre todo, geológicos. Asimismo, hizo una descripción detallada de los salones y de la génesis de la caverna e incluyó una bibliografía básica sobre el tema.

\section{CACAHUAMILPA EN EL MÉXICO POSREVOLUCIONARIO (1920-1936)}

A partir de 1910 Cacahuamilpa desapareció de las fuentes hemerográficas y documentales, y fue hasta la década de los veinte que se volvió a tratar el tema, lo que no es extraño dado que para llegar a la gruta había que pasar por el estado de Morelos, zona zapatista que durante los años de la revolución mexicana fue escenario de intensos conflictos. Los cambios ocurridos en el país en esa época convulsa también alcanzaron a la caverna. Para la década de los años veinte ya se podía llegar a ella por carretera, y el automóvil comenzaba a ser un medio de transporte más común. A decir de Leopoldo Salazar Salinas, director del Instituto Geológico de México, la iniciativa para hacer un camino de la capital de la república a la caverna fue del Centro de Ingenieros, cuyos miembros, después de una excursión al lugar, decidieron que era necesario fomentar su conservación y para ello designaron como autoridad responsable al Instituto antes mencionado. Salazar (1922, pp. 3-17) publicó un relato de su viaje en coche desde la ciudad de México a Cacahuamilpa, una verdadera novedad que contrasta con todas las descripciones del camino hechas hasta entonces, que pasaron del caballo al ferrocarril y, finalmente, al invento que transformaría la forma de vida de los habitantes del planeta en la pasada centuria.

El camino transcurría por la calzada de Tlalpan hasta Huipulco. De ahí se llegaba hasta la calzada de Xochimilco y comenzaba el ascenso al Ajusco hasta el pueblo de Topilejo. En una hora se alcanzaba Parres, la zona más alta de la carretera, y después de 20 minutos el poblado de Tres Marías. En el descenso al valle se veían haciendas y pueblos que presentaban "las huellas de la destrucción causada por el movimiento revolucionario que tanta intensidad alcanzó en esta región" (Salazar, 1922, p. 6). El recorrido hasta la ciudad de Cuernavaca tardaba dos horas y media, y de ahí a Cacahuamilpa,

\section{(ㅇ)(1) $\$$}


tres horas y media, de modo que el trayecto total era de aproximadamente seis horas (véase mapa 1 ).

Para el año de 1922, según el relato de Salazar (1922), las caprichosas formaciones a las que los numerosos viajeros les habían dado el aspecto que su imaginación sugería -chivos, fuentes, catedrales, volcanes- se veían todavía más sorprendentes "bajo el influjo de la luz eléctrica con que la munificencia del gobierno [quiso] dotar a esa maravilla de la naturaleza” (p. 10). El contemplar la caverna iluminada también permitía ver que las dimensiones gigantescas que le atribuyeron los viajeros decimonónicos no eran tales, y que su altura y extensión distaba mucho de ser como se había descrito a lo largo de los años. Sin embargo, su belleza y magnificencia no desmereció un ápice. Ya en la tercera década del siglo xx era común realizar el trayecto en automóvil (véase imagen 3).

La caverna de Cacahuamilpa siguió siendo un destino predilecto para los viajeros. En 1923 fue visitada por la conocida poetisa Gabriela Mistral, que escribió un texto dedicado a la célebre gruta. Entre las imágenes que nos legó, es muy bella su descripción del silencio en el interior de la cueva, de las formas caprichosas que recuerdan a las de la naturaleza, de la impresión general que le causó recorrerla. Así, nos dice Mistral (2007), "quisiera hallarme sola en lo hondo de la gruta para oír el silencio perfecto que es su atributo; un silencio no lacerado ni por la caída de las gotas" (p. 97). Por lo demás, no fue de su agrado la instalación de luz eléctrica, que "ilumina con brutalidad las estalactitas. Si la luna conociese las grutas, ¡qué ansia tendría de iluminarlas con su plateado-azul, o su plateado-oro, o su plateado-plata!" (p. 98).

En 1936, durante la gestión del presidente Lázaro Cárdenas, varios sitios fueron nombrados parques nacionales a lo largo del país. Así, el 23 de abril de ese año se publicó en el Diario Oficial de la Federación el decreto que declaró Parque Nacional la región de las Grutas de Cacahuamilpa, en el estado de Guerrero, ya que el gobierno estaba "obligado a conservar los sitios de interés nacional que reporten beneficios a las regiones donde se encuentran, mejorando sus condiciones naturales para hacerlos más accesibles y atractivos al turismo, como medio de promover el interés de nuestro pueblo, por las bellezas naturales que encierra el territorio" ${ }^{10}$

En las décadas posteriores, como parte de los programas encaminados a la promoción turística de la gruta, el gobierno mexicano realizó diferentes

${ }^{10}$ Decreto que declara Parque Nacional la región de las grutas de Cacahuamilpa, en el estado de Guerrero. Diario Oficial de la Federación, 23 de abril de 1936.

\section{(ㅇ)(1) $(3$}



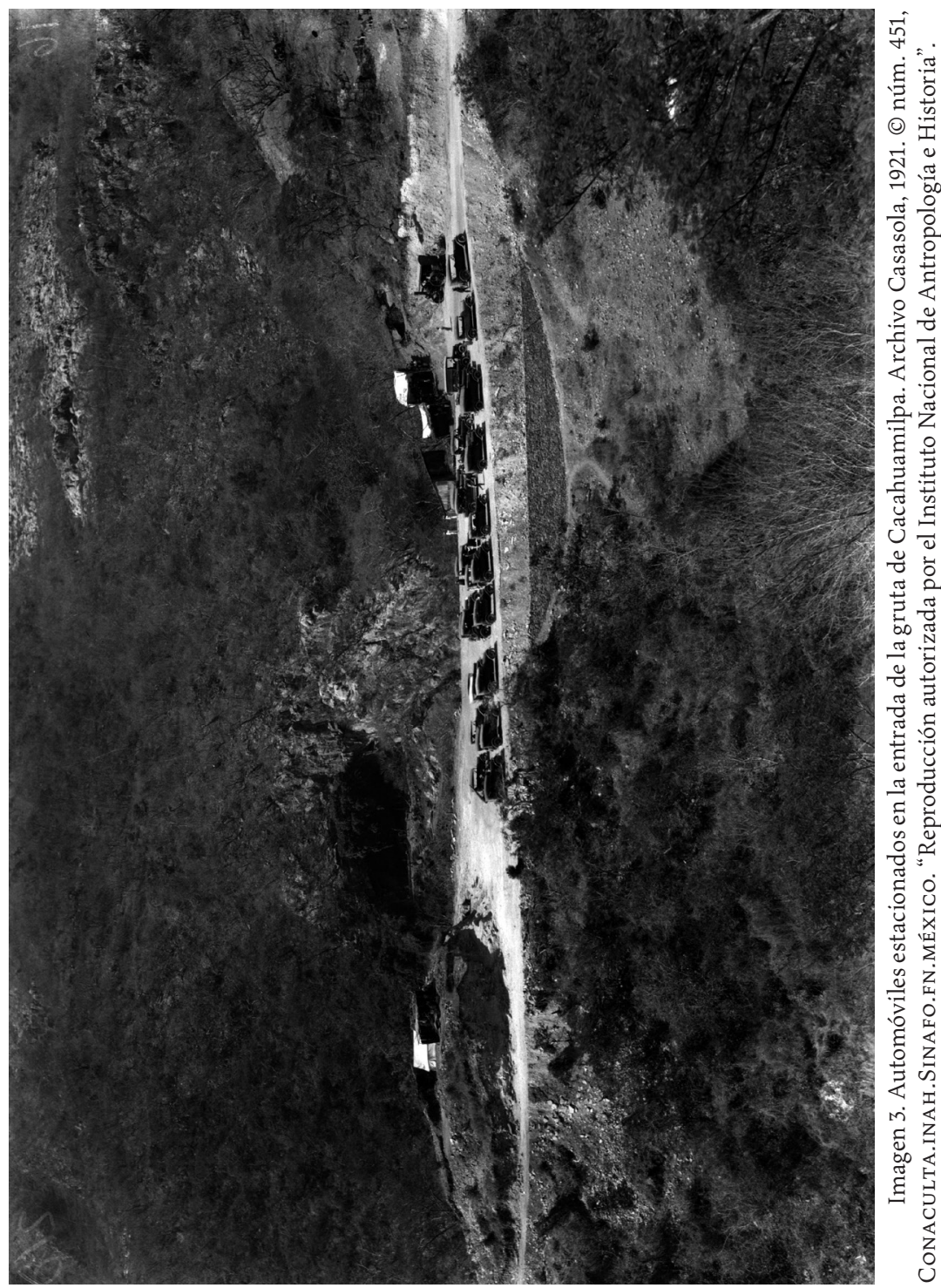

\section{(c) $\$$}

Atribución-NoComercial 4.0

internacional (CC BY-NC 4.0) 
trabajos encaminados a facilitar el acceso de los visitantes. Entre las obras más destacadas cabe mencionar la plataforma de casi dos kilómetros de largo y la iluminación interna de toda la caverna, labores que se completaron en la década de los años sesenta con motivo de la celebración de los Juegos Olímpicos de 1968. Si bien esos servicios hoy en día son muy criticados por los cambios que sufrió la cueva en su aspecto original, lo cierto es que facilitan el acceso a personas de toda edad y condición, que de otra manera no podrían apreciar la grandiosidad de esta excepcional forma natural.

\section{CONSIDERACIONES FINALES}

En este trabajo se ha hecho un recorrido de un siglo a través del México decimonónico, y de los primeros años del siglo xx tomando como referencia la historia de un monumento natural célebre por su belleza. Pudimos conocer las impresiones de los primeros visitantes, algunos relatos de viajeros, las pioneras expediciones científicas, las inversiones que se hicieron en la zona e incluso la declaración de la gruta de Cacahuamilpa como Parque Nacional. Todo ello nos ha permitido, de manera contextual, echar un vistazo al desarrollo del país, a las dificultades de todo tipo que se vivieron en el primer siglo de vida independiente de México, al crecimiento económico en el porfiriato -contexto en el cual la gruta tuvo un papel central como destino de las inversiones en ferrocarriles y caminos-, los avances tecnológicos, como la instalación de luz eléctrica en la caverna y la construcción de una carretera en la década de los años veinte. Es decir, a partir del estudio de la gruta nos hemos podido asomar a un siglo de la historia nacional.

A manera de epílogo, cabe mencionar que, emulando el proyecto de la Compañía Explotadora de las Grutas de Cacahuamilpa, en abril de 1995 -curiosamente un siglo después de la concesión otorgada a José Nozari por el gobierno del estado de Guerrero-, en un contexto de profunda crisis económica y entre lo anecdótico y lo increíble, el gobierno mexicano, a través del entonces Instituto Nacional de Ecología, concesionó el Parque Nacional Grutas de Cacahuamilpa al empresario canadiense Barry Sendel, conocido por sus diseños para Disneylandia y los Estudios Universal. Este personaje pretendía transformar la gruta en un proyecto de atracciones y turismo denominado "Las Grutas del Tiempo", en donde no faltarían los dinosaurios al estilo Parque Jurásico (Vera, 1995, pp. 60-65). Por absurdo que parezca, el canadiense llegó a administrar el Parque durante un par de meses, hasta que

\section{(이요 $\circledast$}


la presión pública, en particular la ejercida por los habitantes de los pueblos aledaños y grupos ecologistas, logró revertir la desafortunada concesión. Esta situación representó un antecedente importante que definió la organización social de la administración del Parque Nacional, que a partir del 1 de enero de 2002 es gestionada en un esquema conjunto entre los pobladores locales y la Comisión Nacional de Áreas Naturales Protegidas. Hoy en día, el Parque recibe más de 300000 visitantes al año, y por su invaluable patrimonio geológico es una de las principales atracciones naturales del estado de Guerrero, así como un destino tradicional para visitantes de todas partes del mundo. En resumen, tal vez el término más adecuado para describir la gruta de Cacahuamilpa es el que el legendario Johnny (Tarzán) Weishmuller dejó en uno de sus muros en 1947. Escribió simplemente: Wonderful.

\section{LISTA DE REFERENCIAS}

Aguilar Ochoa, A. (2007). Los inicios de la litografía en México: el periodo oscuro. Anales del Instituto de Investigaciones Estéticas, 90, 65-100.

Anónimo (1838). La Gruta de Cacahuamilpa. En Calendario de las Señoritas Megicanas para el año de 1838 (pp. 159-183). México: Imprenta de Mariano Galván.

Arróniz, M. (1858). Manual del viajero en Méjico o compendio de la historia de la ciudad de Méjico. París: Librería de Rosa y Bouret.

Bablot, A. (1997). La Academia de San Carlos. Mirada retrospectiva. En I. Rodríguez Prampolini (comp.), La crítica de arte en México en el siglo xIx. Estudios y documentos II (1810-1858) (pp. 171-178). México: Instituto de Investigaciones Estéticas-UNAM.

Bárcena, M. (1874). Viaje a la caverna de Cacahuamilpa; datos para la geología y la flora de los estados de Morelos y Guerrero. México: Imprenta del Gobierno.

Bárcena, M. (1895). El hombre prehistórico en México. México: Congreso Internacional de Americanistas.

Beltrán y Puga, G. (1892). Reseña de una excursión a la caverna de Cacahuamilpa y a la gruta "Carlos Pacheco". México: Sociedad Antonio Alzate/Imprenta del Gobierno Federal en el Ex Arzobispado.

Blasio, J. L. (1903). Maximiliano íntimo. El emperador Maximiliano y su corte. Memorias de un secretario particular. París: Librería de la Viuda de C. Bouret.

Boletín del Instituto Nacional de Geografía y Estadística de la República Mexicana, presentado al Supremo Gobierno de la Nación por la Junta menor del mismo cuerpo (1839-1850). México: Imprenta de Galván a cargo de Mariano Arévalo.

\section{()ㅜ(1) $\$$}


Bonet, F. (1998). Espeleología de la región de Cacahuamilpa. Boletín del Instituto de Geología, 90, 23-88.

Burke, P. (2012). ¿Qué es la historia cultural? Barcelona: Paidós.

Bustamante, C. M. (1836). Mañanas de la Alameda de México. Publicadas para facilitar a las señoritas el estudio de la historia de su país (t. II). México: Imprenta de la Testamentaría de Valdés.

Calderón de la Barca, A. (2012). Diario de Ángel Calderón de la Barca, primer ministro de España en México: incluye sus escalas en Cuba. M. Soto (ed.). México: Secretaría de Relaciones Exteriores-Consultoría Jurídica-Dirección General del Acervo Histórico Diplomático/Southern Metodist Univesity.

Calderón de la Barca, M. (1974). La vida en México. Durante una residencia de dos años en ese país [ $4^{\mathrm{a}}$. ed.]. México: Porrúa.

Carlota de Bélgica. (20 de mayo de 1866). Carta de S. M. la Emperatriz. La Sociedad, p. 3.

Carmona, D. (2014a). Decreto de creación del estado de Guerrero. Recuperado de http://www.memoriapoliticademexico.org/Efemerides/5/15051849.html

Carmona, D. (2014b). Se crea el estado de Morelos. Recuperado de http://www.me moriapoliticademexico.org/Efemerides/4/17041869.html

Castillo, A. del (16 de octubre de 1879). Ciencias. Gruta de Cacahuamilpa. El Siglo Diez y Nueve (XxxIx)76, p. 3.

Caverna de Cacahuamilpa (1855). En M. Orozco y Berra (coord.), Apéndice al Diccionario Universal de Historia y de Geografía. Colección de artículos relativos a la república Mexicana (t. viII, pp. 415-418). México: Imprenta de J. M. Andrade y F. Escalante.

Crespo, H. (2011). El sistema ferroviario de Morelos. En H. Crespo (coord.), Creación del estado, leyvismo y porfiriato (t. vi, pp. 541-568). En H. Crespo (dir.). Historia de Morelos. Tierra, gente, tiempos del Sur. México: Congreso del Estado de Morelos-LI Legislatura/Universidad Autónoma del Estado de Morelos/Ayuntamiento de Cuernavaca/Instituto de Cultura de Morelos.

Diez, D. (1967). Bosquejo histórico geográfico de Morelos [2ª . ed.]. Cuernavaca, Morelos: Editorial Tlahuica.

Fisher, H. T. y Hall Fisher, M. (1966). Life in Mexico. The Letters of Fanny Calderón de la Barca. With New Material from the Author's Private Journals. Nueva York: Anchor Books, Doubleday Company.

Flores, T. (1909). Boletín de la Sociedad Geológica Mexicana, vI, 93-111. México: Sociedad Geológica Mexicana.

Fossey, M. (1844). Viage a Méjico. México: Imprenta de Ignacio Cumplido.

García Cubas, A. (1874). Una excursión a la caverna de Cacahuamilpa. En Escritos diversos. De 1870 a 1874 (pp. 127-162). México: Imprenta de Ignacio Escalante.

\section{()(1) $\$$}


Gondra, I. R. (1844). Gruta de Cacahuamilpa. En El Liceo Mexicano (t. I, pp. 371-377). México: Imprenta de J. M. Lara.

Gros, B. (1865). Renseignements destinés aux voyageurs qui auront à étudier les monuments anciens situés dans les environs du Mexique. En Archives de la Commission Scientifique du Mexique (t. I, pp. 143-144). París: Imprimiere Impérale.

Gutiérrez Viñuales, R. (2011). Italia y la estatuaria pública en Iberoamérica. Algunos apuntes. En M. Sartor (coord.), América Latina y la cultura artística italiana. Un balance en el Bicentenario de la Independencia Latinoamericana (pp. 221-243). Buenos Aires: Instituto Italiano di Cultura.

Iturbide, T. (1917). Reseña descriptiva de la gruta de Cacahuamilpa. Iguala, México: s. p. i.

Huerta, M. T. (1993). Empresarios del azúcar en el siglo XIX. México: INAH.

La caverna de Cacahuamilpa. (1850). Boletín del Instituto Nacional de Geografía y Estadística de la República Mexicana (pp. 59-68). México: Tipografía de R. Rafael.

La exposición Tangassi (1997). En I. Rodríguez Prampolini (comp.), La crítica de arte en México en el siglo XIX. Estudios y documentos II (1810-1858) [2 2 . ed.] (pp. 136-137). México: IIE-UNAM.

Lagunas Rodríguez, Z. (abril-junio, 1976). Enterramientos humanos explorados en Cacahuamilpa, Guerrero. Boletín INAH, 17, época II, 41-46.

Landesio, E. (1868). Excursión a la Caverna de Cacahuamilpa y ascensión al cráter del Popocatépelt. México: Imprenta del Colegio de Tecpam.

Matabuena Peláez, T. (ed.) (2008). Estudio introductorio. En E. Landesio, Excursión a la caverna de Cacahuamilpa y ascensión al cráter del Popocatépelt. México: Universidad Iberoamericana.

Mayer, B. (1953). México, lo que fue y lo que es. México: FCE.

Memorias y Revista de la Sociedad Científica Antonio Alzate (2004). Recuperado de: http://www.palaciomineria.unam.mx/eventos/ant_memorias_y_revistas.htm

Mexican National Commission. (1904). Historical Data Concerning the Mining District of Taxco de Alarcon, State of Guerrero. Prepared by Order of a Committee of Miners of Said District, for the purpose of Exhibiting the same at the Dan Louis Exposition. San Luis, Misuri: Universal Exposition.

Mistral, G. (2007). Las grutas de Cacahuamilpa. En Zegers, P. (ed.), Gabriela y México (pp. 95-98). Santiago de Chile: RIL Editores.

Nosari, E. (1899). Una visita a las grutas de Cacahuamilpa. México: Imprenta y Casa Editorial J. M. Mellado.

Ortega y Medina, J. A. (1953). Prólogo y notas. En B. Mayer (1953), México, lo que fue y lo que es. México: FCE.

\section{()(1) $\$$}


Ortiz Herrán, S. (1973). Caminos y transportes mexicanos al comenzar el siglo xIX. Recuperado de http://revistas.bancomext.gob.mx/rce/magazines/510/6/RCE10.pdf

Portilla, A. (17 de marzo de 1874). Viaje por Tierracaliente. La cueva de Cacahuamilpa. La Iberia, 2125, pp. 1-2.

Ramírez Rodríguez, R. (2013). Atisbo historiográfico de la literatura viajera decimonónica en México. Trashumante. Revista Americana de Historia Social, 1, 114-136.

Reynoso Jaime, I. (2005). La conformación de las elites locales. El caso de la región de Tetecala, 1850-1910. (Tesis de licenciatura inédita). Facultad de Humanidades-Universidad Autónoma del Estado de Morelos.

Ribera Carbó, E. (2012). Moviendo telares e iluminando la ciudad. De la industria local a la globalización empresarial en la electrificación de Orizaba, México, 18901919. Ponencia presentada en el simposio internacional Globalización, Innovación y Construcción de Redes Técnicas Urbanas en América y Europa, 1890-1930, Universidad de Barcelona, Barcelona, España.

Riva Palacio, V. (17 de febrero de 1874). El artículo 84 de la Constitución. El Radical, 85, p. 1.

Robelo, C. (28 de enero de 1886). Los estados mexicanos. Cacahuamilpa. Sus grutas. Crónica Hispano-Americana, XxVII(2), 14-15.

Robelo, C. (30 de enero-3 de febrero de 1886). La gruta de Cacahuamilpa. Municipio Libre. XII(9-10), 1.

Robelo, C. (7 de febrero de 1886). Los estados mexicanos. Cacahuamilpa. Sus grutas. Crónica Hispano-Americana, x(2653), 2.

Rodríguez Prampolini, I. (comp.) (1997). La crítica de arte en México en el siglo XIX. Estudios y documentos II (1810-1858). México: Instituto de Investigaciones Estéticas-UNAM.

Rodríguez Rangel, V. y Valenzuela A. C. (2010). Arte. En G. Gómez-Aguado (coord.), Estudios Mexicanos: historia, arte y literatura. T. 3. Siglo XIX (pp. 165-267). México: Centro de Enseñanza para Extranjeros-unAm.

Romero de Terreros, M. (1953). El barón Gros y sus vistas de México. México: Imprenta Universitaria.

Salazar Salinas, L. (1922). A la caverna de Cacahuamilpa en automóvil. México: Departamento de Exploraciones y Estudios Geológicos-Secretaría de Industria, Comercio y Trabajo/Instituto Geológico de México.

Toussaint, A. (1997). Ubicación y descripción arquitectónica de las haciendas. Relación y breve reseña de las haciendas de Morelos. En B. von Mentz, B. Sharrer et. al., Haciendas de Morelos (pp. 217-379). México: Gobierno del Estado de Morelos/ Instituto de Cultura de Morelos/Consejo Nacional para la Cultura y las Artes/ Miguel Ángel Porrúa.

\section{()(1) $\$$}


Velázquez de León, J. (9 de febrero de 1882). La caverna de Cacahuamilpa. El Minero Mexicano, VIII(50), pp. 13-16.

Vera, R. (1995). El concesionario canadiense piensa convertir las Grutas de Cacahuamilpa en el parque nacional más tecnificado del mundo. Proceso, 971, 60-65.

X (12 de septiembre de 1864). La caverna de Cacahuamilpa. Méjico. La América. Crónica hispano-americana, pp. 9-11.

Zarco, F. (1852). La caverna de Cacahuamilpa. En El presente amistoso dedicado a las señoritas mexicanas (t. III, pp. 430-439). México: Imprenta de Ignacio Cumplido.

\section{OTRAS FUENTES}

\section{Bibliografía}

Anónimo (27 de marzo de 1874). Generosidad. La Iberia, 2135, p. 3.

Anónimo (3 de marzo de 1875). Visita a la gruta de Cacahuamilpa. La Iberia, 2419, p. 3. Anónimo (9 de octubre de 1879). Otra gruta en Cacahuamilpa. El Siglo Diez y Nueve, $\operatorname{XxxIX}(76), 12381$, p. 3.

Anónimo (29 de marzo de 1881). La expedición de Cacahuamilpa. El Nacional, II(113), p. 3.

Anónimo (29 de marzo de 1881). Lo sentimos. El Telégrafo, I(30), p. 3.

Anónimo (31 de marzo de 1881). La expedición a Cacahuamilpa. El Nacional, II(114), p. 3.

Anónimo (3 de abril de 1881). La Expedición a la gruta de Cacahuamilpa. Mal fin de ella. La Voz de México. Revista Semanaria, XII(75), p. 1.

Anónimo (12 de noviembre de 1886). Noticias del Repórter. Buena idea. La Patria, x(2891), p. 3.

Anónimo (13 de noviembre de 1886). About Town. The Two Republics, XxIII(105), p. 2.

Anónimo (6 de julio de 1888). Una buena noticia para los turistas. El Nacional, XI(5), p. 3.

Anónimo (29 de febrero de 1896). The caves of Cacahuamilpa. Twenty four hours spend amid the wonders of natures. The Mexican Herald, I(182), p. 7.

Anónimo (5 de julio de 1896). En las grutas de Cacahuamilpa. La Convención Radical Obrera, x(514), p. 3.

Anónimo (7 de agosto de 1898). Las grutas de Cacahuamilpa. Su reproducción en el Gran Certamen de París. La Convención Radical Obrera, XII(557), p. 2.

Anónimo (24 de junio de 1905). Poder Legislativo. Sesión del día 29 de mayo de 1905. Periódico Oficial del Gobierno del Estado de Guerrero, xxvin(29), pp. 2-3.

\section{(ㅇ)(1) $\$$}


C. de M. (1838). La Gruta de Cacahuamilpa en Mégico. En Semanario Pintoresco Español (t. III, pp. 557-58 y 563-565). Madrid: Imprenta de Tomás Jordán.

F. F. (3 de abril de 1881). The excursion to Cacahuamilpa. The Two Republics, xIV(41), pp. 1-2.

García Cubas, A. (1888). Diccionario biográfico, histórico y geográfico de los Estados Unidos Mexicanos (t. II). México: Oficina Tipográfica de la Secretaría de Fomento.

Girard, J. (1859). Excursion d'un touriste au Mexique pendant l'année 1854. Tours: A. Mame et. Cie.

Ibáñez, F. J. (12 de julio de 1896). Estatutos de la Compañía Balnearia de Ixtapan de la Sal, Explotadora de las Grutas de Cacahuamilpa, Sociedad Anónima. La Convención Radical Obrera, x(515), pp. 2-3.

Ramírez, S. (1885). Biografía del Señor D. Joaquín Velázquez de León. México: Oficina Tipográfica de la Secretaría de Fomento.

Regagnon, J. L. (25 de julio de 1888). La grotte de Cacahuamilpa. Le Trait D’Union, $\operatorname{xxxv}(80), 21$, p. 3.

Sociedad Mexicana de Geografía y Estadística (7 de junio de 1858). Acta núm. 17 de la sesión del día 4 de junio de 1858. La Sociedad, p. 2.

Staff Correspondent (25 de octubre de 1908). The Caves of Cacahuamilpa. One of the wonders of Mexico. The Mexican Herald, xxviI(55), pp. 17-18, 20.

Traveler, A. (12 de agosto de 1900). Saunterings in Summerland. The Caves of Cacahuamilpa Not Visible. A Hurtful Monopoly. On Horseback in Guerrero. Types, Scenes and Incidents. The Mexican Herald, Ix(292), pp. 1, 5.

X (16 de febrero de 1895). La gruta de Cacahuamilpa. El Amigo de la Verdad, $4^{a}$ época, XXII, t. VII(20), pp. 3-4. 